\title{
Development of a vulnerability map for groundwater inundation of a riverside alluvial plain
}

\author{
${ }^{1}$ Department of Construction Safety and Disaster Prevention, Daejeon University, Daejeon 34520, Republic of Korea \\ ${ }^{2}$ K-water Convergence Institute, Korea Water Resources Corporation, Daejeon 34045, Republic of Korea; *Corresponding author, \\ E-mail:dgkim@kwater.or.kr
}

(Received: August 7, 2017; Revised accepted: February 5, 2018)

https://doi.org/10.18814/epiiugs/2018/018009

Groundwater inundation occurs when rivers with high water levels are hydraulically connected to the adjacent riversides. Huge barrages constructed in South Korea have caused the river water levels and groundwater levels in the riversides to increase. We used a discriminant model with seven input variables, namely the sediment thickness, difference between the land elevation and river water level, difference between the groundwater and river water levels, soil drainage type, topsoil texture, subsoil texture, and hydrological soil feature classification, to develop a map of the groundwater inundation vulnerability along the basins of the Nakdong River. We estimated the groundwater levels in unmonitored areas with a linear regression model developed from the relationship between the distance from the river and the depth to the groundwater in 91 monitoring wells. We produced a grid map for the vulnerability with an optimum grid size of $100 \mathrm{~m}$. We validated the groundwater inundation vulnerability map by comparing highly susceptible areas with swampy fields observed in a field survey. This result indicates that the vulnerability map will be helpful to forecast and prepare inundation in the riversides during the rainy season when the river water levels are inevitably high.

\section{Introduction}

Continuous groundwater pumping for irrigation has meant that the groundwater levels in alluvial plains bordering river channels have decreased over recent decades in South Korea. Data from national monitoring of groundwater wells indicate that the average groundwater levels in some large plains close to rivers are generally lower than the river water levels because of groundwater pumping (MLTM, 2012). Depending on the season and rainfall, groundwater depletion or inundation has often produced in the agricultural plain adjacent to the river. In 2008, the government launched the Four Major Rivers Restoration Project (4MRRP) as part of the 'Reviving the Rivers: A New Korea' initiative, the aim of which was to solve water hazard related problems. The five core tasks of the 4MRRP were 1) to secure the water supply, 2) mitigate flood damage, 3) improve the water quality and restore the ecology, 4) create public spaces for residents, and 5) develop river-oriented communities (MLTM. 2010). Sixteen large barrages and three large dams were planned and constructed to store water and control flooding. The construction of the large barrages caused the groundwater levels to increase by up to $3 \mathrm{~m}$ because the river water level in the riverside plain was higher after damming than in the pre-construction period (Kim et al., 2012; Lee et al., 2012; Kim et al., 2013). This increase in groundwater levels, however, has given rise to public complaints about the inundation of the riverside during the barrage construction, with some people insisting that the project would cause additional risks of groundwater flooding in the fields.

Due to hydraulic conductivity, the groundwater level rises more slowly than surface water during a rainfall event and the water level is also maintained at a high level for a longer time in groundwater than surface water. Increases in the groundwater level can result in high soil moisture contents in the vadose zone and reduced rates of rainfall infiltration (Chen and Hu, 2004). Factors such as soil characteristics, topographic features, depth to the groundwater, and the interactions between river water and groundwater trigger a process of inundation or swamp development when a river is dammed.

Flooding is classified into five types by the UK Environmental Law Association (UKELA, 2017). Coastal flooding results from high tides that cause sea levels to rise above normal and force sea water onto the land. River flooding is generally produced by prolonged and extensive rain that induces high river levels, overflowing rivers, and inundation of the riverside. Flash floods are fast moving and unexpected events that are usually caused by heavy rain when flood defences fail or drainage systems are inadequate. Groundwater flooding occurs when the underground water levels rise above the normal levels and approach the surface. Sewer flooding occurs when sewerage systems fail because their capacity is overwhelmed during heavy rainfall. There are two common types of groundwater flooding. First, groundwater flooding can occur when the water table in an unconfined aquifer rises rapidly above the land surface in response to extreme rainfall and a low water absorbing capacity. This occurs, for example, in chalk outcrops in Europe. Groundwater flooding can also occur in response to heavy rainfall and high river water levels if groundwater levels rise to the surface in shallow unconsolidated sedimentary aquifers that are connected hydraulically to adjacent river networks. 
Groundwater flooding related to high water levels has been studied extensively in European countries (Shlemon, 1995; Dreher and Gunatilaka, 1996, 1998; Mucha, 1999; Habets et al., 2008, 2010; Cobby et al., 2009; Adams et al., 2010; Naughton et al., 2012). In the Dresden area, $16 \%$ of all the flooding that occurs is caused by increases in the groundwater level close to the River Elbe (Kreibich et al., 2009; Sommer et al., 2009). In England, shallow groundwater levels create swampy soil, and the groundwater discharge rates decrease because of the high water levels, resulting in inundation in areas with chalk formations (MacDonald et al., 2008; Hughes et al., 2012).

In general, a numerical model can be used more effectively and frequently to estimate the range of inundation in the riversides but lots of efforts are required to get input data and sometimes it is impossible to get them in a large area. Therefore a simplified tool is required to forecast groundwater level and inundation possibility in the riverside where is affected by a rapid change of river water level controlled by water gate during a rainy season.

The purpose of this study is to develop a generalized method for estimating groundwater levels in the riverside, and also to draw a regional vulnerability map of groundwater inundation for the plains near the Nakdong River in South Korea. We then test the effectiveness of the vulnerability map by comparing the produced map with field survey data of the actual swampy or inundated land and numerical model results.

\section{Study Area}

The Nakdong River is about $506 \mathrm{~km}$ long and is in the southeastern region of South Korea (Fig. 1). The river width ranges from only a few meters in its upper reaches to several hundred meters in the lower reaches close to its estuary. The watershed includes numerous floodplains in the middle and lower reaches that are mostly used for growing rice and cultivating cash crops such as Citrullus vulgaris, Cucumis melo, paprika, grapes, and strawberry. Given that we wanted to explore the effects of surface water levels that were controlled by the barrage floodgates on the groundwater levels in the riparian zone, this study was limited to the basins of the Nakdong River from the lowest Haman Barrage to the uppermost Sangju Barrage (Fig. 1).

The distribution, both the area and percentage, of the different soil types in the barrage watershed along the Nakdong River is shown in Table 1. Top soil is the upper, outermost layer of soil with the highest

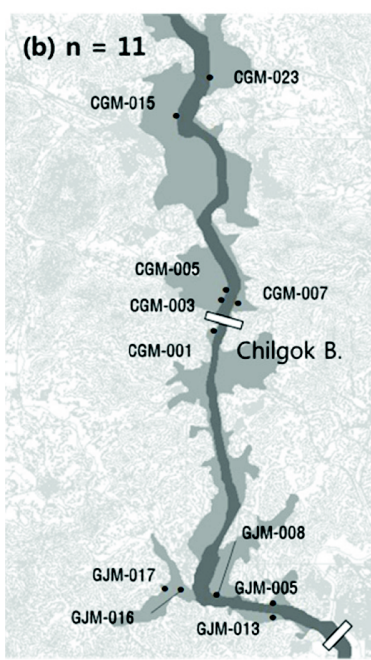

Gangjeong Koryeong B.

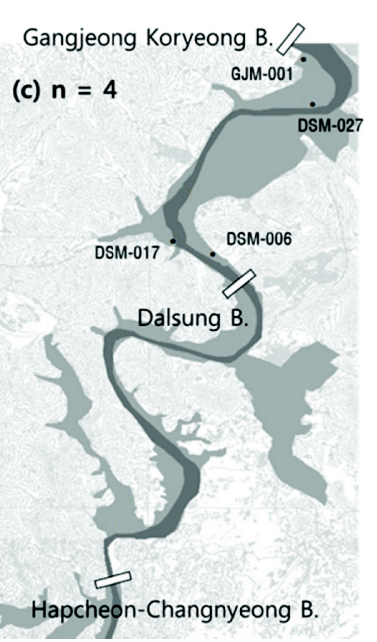

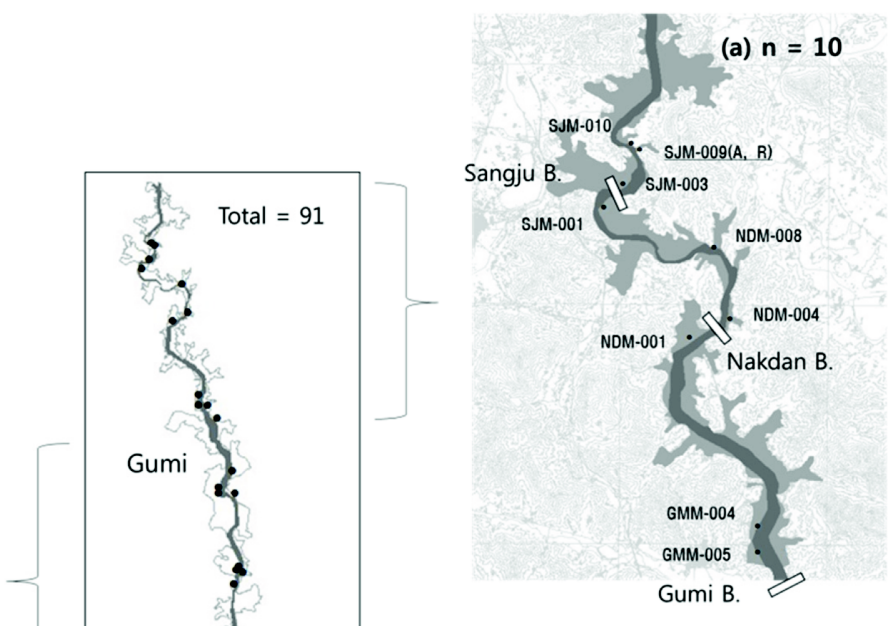

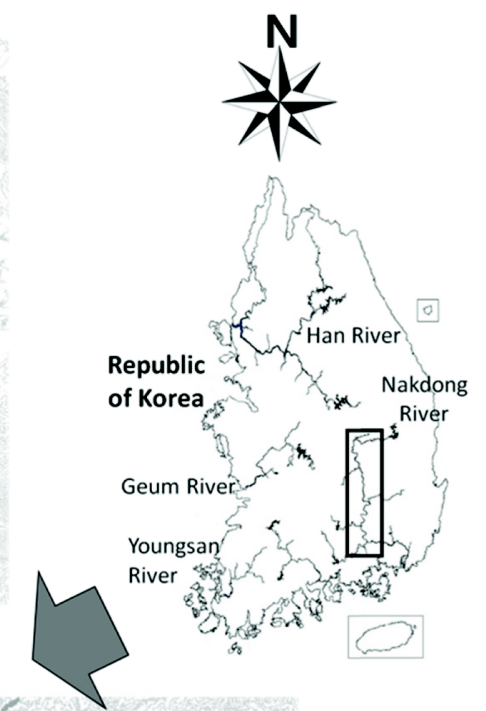

(d) $n=36$

Riverside alluvial deposit

Nakdong river
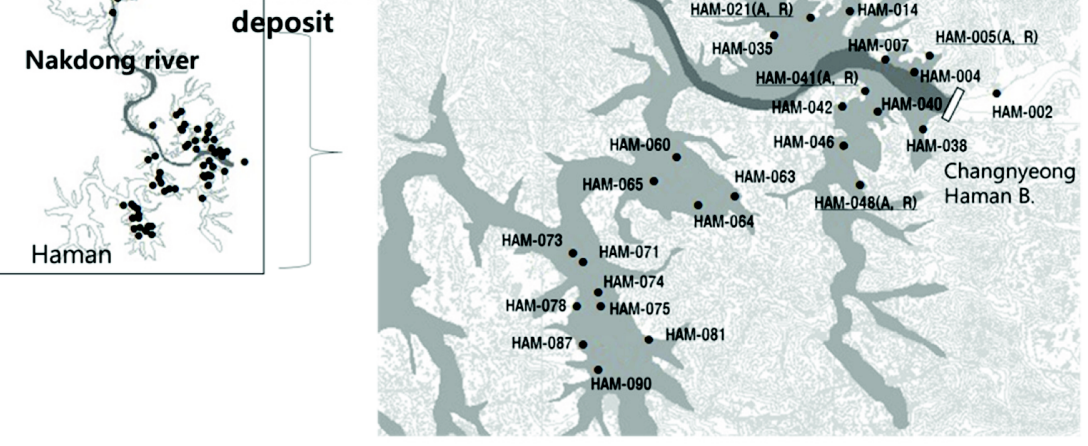

Figure 1. Distribution of riverside alluvial deposits and groundwater monitoring wells in the study area (revised from Kim et al., 2015). 
Table 1. Composition of soil texture in the study area (Area in $\mathrm{km}^{2}$; P in \%)

(a) Topsoil texture

\begin{tabular}{|c|c|c|c|c|c|c|c|c|c|c|c|c|c|c|c|c|c|c|}
\hline \multirow[t]{2}{*}{ Content } & \multicolumn{2}{|c|}{$\begin{array}{c}\text { Changnyung- } \\
\text { Haman B. }\end{array}$} & \multicolumn{2}{|c|}{$\begin{array}{l}\text { Hapcheon- } \\
\text { Changnyung B. }\end{array}$} & \multicolumn{2}{|c|}{ Dalsung B. } & \multicolumn{2}{|c|}{$\begin{array}{l}\text { Gangjeong- } \\
\text { Koryung B. }\end{array}$} & \multicolumn{2}{|c|}{ Chilgok B. } & \multicolumn{2}{|c|}{ Gumi B. } & \multicolumn{2}{|c|}{ Nakdan B. } & \multicolumn{2}{|c|}{ Sangju B. } & \multicolumn{2}{|c|}{ Total } \\
\hline & Area & $\mathrm{P}$ & Area & $\mathrm{P}$ & Area & $\mathrm{P}$ & Area & $\mathrm{P}$ & Area & $P$ & Area & $\mathrm{P}$ & Area & $\mathrm{P}$ & Area & $\mathrm{P}$ & Area & $\mathrm{P}$ \\
\hline Silty clay loam & & & & & & 1.7 & & 0.0 & & 1.1 & 5.4 & 16 & 9.0 & 19.3 & 1.9 & 1.0 & 22.7 & 5.1 \\
\hline & & 7.0 & 3.7 & 16.8 & 3.7 & 15.9 & 23.8 & 32.1 & 15.4 & 34.1 & 13.2 & 39.1 & 19.6 & 42 & 117.4 & 66.2 & 198 & 45 \\
\hline Sandy loam & 5.2 & 28.0 & 2.2 & 10.3 & 4.4 & 19.1 & 10.9 & 14.7 & 7.5 & 16.6 & 0.8 & 2.5 & 0.7 & 1.5 & 8.5 & 4.8 & 40.2 & 9.1 \\
\hline Fine sandy loam & & 7.6 & 4.1 & 18.9 & 5.7 & 24.8 & 10 & 13.5 & 5.9 & 13 & 2.7 & 8.1 & 7.2 & 15.5 & 21.7 & 12.2 & 58.8 & 13.4 \\
\hline Clay loam & 0.0 & 0.0 & 0.0 & 0.0 & 0.0 & 0.0 & 0.0 & 0.0 & 0.0 & 0.0 & 0.1 & 0.3 & 0.0 & 0.0 & 0.0 & 0.0 & 0.1 & 0.0 \\
\hline Loamy sand & 0.4 & 2.0 & 1.7 & 7.8 & 0.8 & 3.4 & 0.6 & 0.8 & 0.6 & 1.4 & 1.4 & 4.2 & 2.6 & 5.5 & 1.2 & 0.7 & 9.3 & 2.1 \\
\hline Loamy fine sand & 1.4 & 7.6 & 0.4 & 1.8 & 2.3 & 10.1 & 8.6 & 11.6 & 4.8 & 10.5 & 7.5 & 22.2 & 4.6 & 9.8 & 4.8 & 2.7 & 34.3 & 7.8 \\
\hline Loamy coarse sand & 0.0 & 0.0 & 0.0 & 0.2 & 0.3 & 1.2 & 0.2 & 0.2 & 0.0 & 0.0 & 0.0 & 0.0 & 0.0 & 0.0 & 0.0 & 0.0 & 0.5 & 0.1 \\
\hline Loam & 6.6 & 35.4 & 64 & 29.3 & 5.4 & 23.6 & 20.1 & 27.0 & 10.5 & 23.3 & 2.6 & 7.7 & 3.0 & 6.4 & 21.9 & 12.3 & 76.4 & 17.4 \\
\hline Total & 18.6 & 100.0 & 21.8 & 100.0 & 22.9 & 100.0 & 74.2 & 100.0 & 45.2 & 100.0 & 33.7 & 100.0 & 46.7 & 100.0 & 177.3 & 100.0 & 440.3 & 100. \\
\hline
\end{tabular}

(b) Subsoil texture

\begin{tabular}{|c|c|c|c|c|c|c|c|c|c|c|c|c|c|c|c|c|c|c|}
\hline \multirow{2}{*}{ Content } & \multicolumn{2}{|c|}{$\begin{array}{c}\text { Changnyung- } \\
\text { Haman B. }\end{array}$} & \multicolumn{2}{|c|}{$\begin{array}{c}\text { Hapcheon- } \\
\text { Changnyung B. }\end{array}$} & \multicolumn{2}{|c|}{ Dalsung B. } & \multicolumn{2}{|c|}{$\begin{array}{l}\text { Gangjeong-- } \\
\text { Koryung B. }\end{array}$} & \multicolumn{2}{|c|}{ Chilgok B. } & \multicolumn{2}{|c|}{ Gumi B. } & \multicolumn{2}{|c|}{ Nakdan B. } & \multicolumn{2}{|c|}{ Sangju B. } & \multicolumn{2}{|c|}{ Total } \\
\hline & Area & $\mathrm{P}$ & Area & $\mathrm{P}$ & Area & $\mathrm{P}$ & Area & $\mathrm{P}$ & Area & $\mathrm{P}$ & Area & $\mathrm{P}$ & Area & $\mathrm{P}$ & Area & $\mathrm{P}$ & Area & $\mathrm{P}$ \\
\hline Fine silty & 1.0 & 5.4 & 2.1 & 9.6 & 1.7 & 7.3 & 17.9 & 24.1 & 11.0 & 24.3 & 9.4 & 28.1 & 15.3 & 32.8 & 91.7 & 51.8 & 150.1 & 34.1 \\
\hline Coarse silty & 0.0 & 0.0 & 0.0 & 0.0 & 0.4 & 1.8 & 2.2 & 3.0 & 0.1 & 0.1 & 0.9 & 2.8 & 2.1 & 4.5 & 9.2 & 5.2 & 14.9 & 3.4 \\
\hline Sandy, very gravelly & 0.0 & 0.1 & 0.3 & 1.3 & 0.7 & 3.2 & 1.0 & 1.4 & 0.4 & 1.0 & 1.4 & 4.2 & 2.6 & 5.5 & 1.6 & 0.9 & 8.1 & 1.8 \\
\hline Coarse loamy & 5.7 & 30.4 & 7.2 & 33.1 & 11.9 & 51.7 & 26.6 & 35.9 & 15.2 & 33.6 & 3.9 & 11.7 & 7.0 & 15.0 & 33.3 & 18.8 & 110.8 & 25.2 \\
\hline Sandy & 2.9 & 15.7 & 2.2 & 10.1 & 3.6 & 15.8 & 10.7 & 14.3 & 6.3 & \begin{tabular}{|l|}
14.0 \\
\end{tabular} & 7.7 & 22.8 & 6.2 & \begin{tabular}{|l|}
13.3 \\
\end{tabular} & 5.5 & \begin{tabular}{|l|}
3.1 \\
\end{tabular} & \begin{tabular}{|l|}
45.1 \\
\end{tabular} & \begin{tabular}{|l|}
10.2 \\
\end{tabular} \\
\hline Fine loamy & 7.2 & 38.6 & 8.3 & 38.1 & 4.1 & 17.8 & 13.6 & 18.3 & 10.2 & 22.5 & 4.7 & 14.1 & 4.3 & 9.3 & 29.5 & 16.6 & 81.9 & 18.6 \\
\hline Clayey & 1.8 & 9.8 & 1.7 & 7.9 & 0.5 & 2.3 & 2.2 & 3.0 & 2.0 & \begin{tabular}{|l|}
4.4 \\
\end{tabular} & 5.5 & 16.3 & 9.2 & 19.6 & 6.5 & 3.6 & 29.4 & 6.7 \\
\hline Total & 18.6 & 100.0 & 21.8 & 100.0 & 22.9 & 100.0 & 74.2 & 100.0 & 45.2 & 100.0 & 33.7 & 100.0 & 46.7 & 100.0 & \begin{tabular}{|l|}
177.3 \\
\end{tabular} & 100.0 & \begin{tabular}{|l|}
440.3 \\
\end{tabular} & 100.0 \\
\hline
\end{tabular}

concentration of organic matter and microorganisms, and subsoil is the layer of soil under the top soil on the surface of the ground (https:// en.wikipedia.org). At 45\%, silt loam accounted for the highest percentage of topsoil, loam accounted for $17.4 \%$, and there was almost no clay loam. The ratio of loam and sandy loam increased, and the proportion of silt loam decreased significantly, in an upstream direction. Fine silty soil, with a percentage of $34.1 \%$, was the largest component of subsoil, followed by coarse loamy soil, which accounted for $25.2 \%$, and very gravelly sand, which made up only $1.8 \%$. In the downstream area, the proportion of fine silt gradually increased with corresponding decreases in both the fine and coarse loams.

Soil drainage classes refer to the soil's natural ability to allow water to pass through it. Water is held in dense soils such as clay, but passes rapidly through loose soils such as sand. In the downstream watershed, the soil particles generally decrease in size but, when added, organic materials can improve the soil drainage. Therefore, the distribution of the soil drainage classes shows that intermediate drainage classes, such as weakly good and weakly poor, become a main component in the downstream watershed with the result that the proportions of the two extreme classes, very good and very poor, decrease (Table 2, http://soil.rda.go.kr).
We used the minimum infiltration rate for bare soil after prolonged wetting to define the hydrological soil groups as either A, B, C, and D (Nielsen and Hjelmfelt, 1998; USDA, 2005). Group A comprises soils with a low runoff potential and high infiltration rates, even when thoroughly wetted, and mostly includes sand, loamy sand, or sandy loam. Group B includes soils with moderate infiltration rates, namely silt loam or loam. Group C comprises soils with low infiltration rates such as sandy clay loam. Group D comprises soils with the highest runoff potential and low infiltration rates and includes clay loam, silty clay loam, sandy clay, silty clay, or clay. The area covered by group A soils tends to decrease, while that of group B tends to increase, in the downstream direction (Table 3). This reflects the soil composition; that is, the soil particles in group A soils are generally coarser than those in group B.

We used drilling data from 1405 points along the Nakdong River to examine the distribution of the sediment thickness (MLTM, 2010, 2013). The sediments across the whole study area were, on average, $19.4 \mathrm{~m}$ thick; sediments were about 12.0 and $21.9 \mathrm{~m}$ thick in the upstream and downstream regions, respectively (Fig. 2), and reached a maximum thickness of $40 \mathrm{~m}$ near the Haman Barrage. The sediments were mainly comprised of sand, which averaged $48.1 \%$. The 
Table 2. Distribution of the soil drainage classification (Area $\left.=\mathrm{km}^{2} ; \mathrm{P}=\%\right)$

\begin{tabular}{|c|c|c|c|c|c|c|c|c|c|c|c|c|c|c|c|c|c|c|}
\hline \multirow[t]{2}{*}{ Class } & \multicolumn{2}{|c|}{$\begin{array}{c}\text { Changnyung- } \\
\text { Haman B. }\end{array}$} & \multicolumn{2}{|c|}{$\begin{array}{c}\text { Hapcheon- } \\
\text { Changnyung B. }\end{array}$} & \multicolumn{2}{|c|}{ Dalsung B. } & \multicolumn{2}{|c|}{$\begin{array}{l}\text { Gangjeong- } \\
\text { Koryung B. }\end{array}$} & \multicolumn{2}{|c|}{ Chilgok B. } & \multicolumn{2}{|c|}{ Gumi B. } & \multicolumn{2}{|c|}{ Nakdan B. } & \multicolumn{2}{|c|}{ Sangju B. } & \multicolumn{2}{|c|}{ Total } \\
\hline & Area & $\mathrm{P}$ & Area & $\mathrm{P}$ & Area & $\mathrm{P}$ & Area & $\mathrm{P}$ & Area & $\mathrm{P}$ & Area & $\mathrm{P}$ & Area & $\mathrm{P}$ & Area & $\mathrm{P}$ & Area & $\mathrm{P}$ \\
\hline Very poor & 2.07 & 11.1 & 2.26 & 10.4 & 2.26 & 9.9 & 5.24 & 7.1 & 3.85 & 8.5 & 0.37 & 1.1 & 0.32 & 0.7 & 1.59 & 0.9 & 17.95 & 4.1 \\
\hline Very good & 2.56 & 13.8 & 2.47 & 11.3 & 3.96 & 17.3 & 12.32 & 16.6 & 9.24 & 20.5 & 10.86 & 32.3 & 9.31 & 19.9 & 10.25 & 5.8 & 60.97 & 13.8 \\
\hline Poor & 0.04 & 0.2 & 0.04 & 0.2 & 0.02 & 0.1 & 0.00 & 0.0 & 0.33 & 0.7 & 0.00 & 0.0 & 0.00 & 0.0 & 1.30 & 0.7 & 1.72 & 0.4 \\
\hline Weakly poor & 3.75 & 20.2 & 2.33 & 10.7 & 3.38 & 14.8 & 14.29 & 19.2 & 10.00 & 22.1 & 7.11 & 21.1 & 10.11 & 21.7 & 60.11 & 33.9 & 111.09 & 25.2 \\
\hline Weakly good & 4.05 & 21.8 & 6.37 & 29.2 & 7.99 & 34.9 & 31.55 & 42.5 & 10.97 & 24.3 & 8.44 & 25.1 & 17.37 & 37.2 & 79.44 & 44.8 & 166.19 & 37.7 \\
\hline Good & 6.11 & 32.9 & 8.36 & 38.3 & 5.30 & 23.1 & 10.83 & 14.6 & 10.76 & 23.8 & 6.87 & 20.4 & 9.57 & 20.5 & 24.57 & 13.9 & 82.36 & 18.7 \\
\hline Total & 18.59 & 100.0 & 21.82 & 100.0 & 22.92 & 100.0 & 74.23 & 100.0 & 45.15 & 100.0 & 33.65 & 100.0 & 46.69 & 100.0 & 177.25 & 100.0 & 440.28 & 100.0 \\
\hline
\end{tabular}

Table 3. The distribution of hydrologic soil groups throughout the study area $\left(\right.$ Area $\left.=\mathrm{km}^{2} ; \mathrm{P}=\%\right)$

\begin{tabular}{|c|c|c|c|c|c|c|c|c|c|c|c|c|c|c|c|c|c|c|}
\hline \multirow{2}{*}{ Group } & \multicolumn{2}{|c|}{$\begin{array}{c}\text { Changnyung- } \\
\text { Haman B. }\end{array}$} & \multicolumn{2}{|c|}{$\begin{array}{l}\text { Hapcheon-- } \\
\text { Changnyung B. }\end{array}$} & \multicolumn{2}{|c|}{ Dalsung B. } & \multicolumn{2}{|c|}{$\begin{array}{l}\text { Gangjeong-- } \\
\text { Koryung B. }\end{array}$} & \multicolumn{2}{|c|}{ Chilgok B. } & \multicolumn{2}{|c|}{ Gumi B. } & \multicolumn{2}{|c|}{ Nakdan B. } & \multicolumn{2}{|c|}{ Sangju B. } & \multicolumn{2}{|c|}{ Total } \\
\hline & Area & $\mathrm{P}$ & Area & $\mathrm{P}$ & Area & $\mathrm{P}$ & Area & $\mathrm{P}$ & Area & $\mathrm{P}$ & Area & $\mathrm{P}$ & Area & $\mathrm{P}$ & Area & $\mathrm{P}$ & Area & $\mathrm{P}$ \\
\hline A & 6.00 & 32.3 & 8.14 & 37.3 & 8.89 & 38.8 & 20.14 & 27.1 & 12.29 & 27.2 & 9.53 & 28.3 & 9.64 & 20.6 & 18.66 & 10.5 & 93.29 & 21.2 \\
\hline B & 1.69 & 9.1 & 4.06 & 18.6 & 1.73 & 7.6 & 16.04 & 21.6 & 6.30 & 13.9 & 7.41 & 22.0 & 11.25 & 24.1 & 46.69 & 26.3 & 95.18 & 21.6 \\
\hline $\mathrm{C}$ & 1.35 & 7.3 & 0.58 & 2.7 & 0.70 & 3.1 & 5.44 & 7.3 & 2.63 & 5.8 & 1.35 & 4.0 & 2.87 & 6.1 & 10.40 & 5.9 & 25.33 & 5.8 \\
\hline $\mathrm{D}$ & 9.55 & 51.4 & 9.04 & 41.4 & 11.59 & 50.6 & 32.60 & 43.9 & 23.94 & 53.0 & 15.36 & 45.6 & 22.93 & 49.1 & 101.50 & 57.3 & 226.50 & 51.4 \\
\hline Total & 18.59 & 100.0 & 21.82 & 100.0 & 22.92 & 100.0 & 74.23 & 100.0 & 45.15 & 100.0 & 33.65 & 100.0 & 46.69 & 100.0 & 177.25 & 100.0 & 440.28 & 100.0 \\
\hline
\end{tabular}

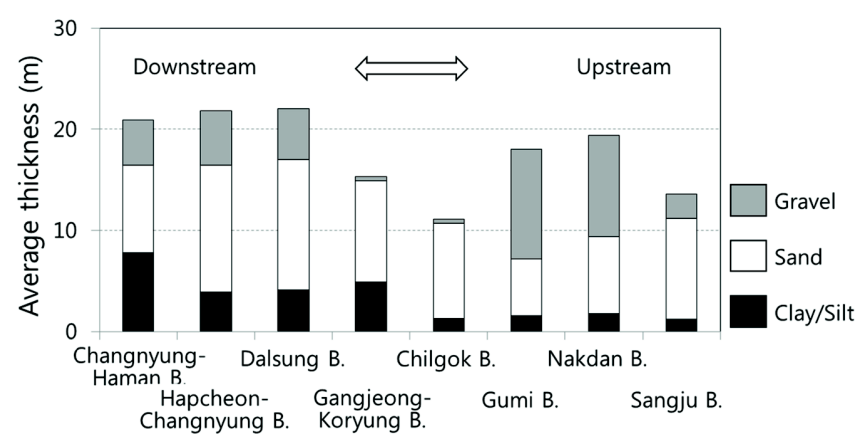

Figure 2. Average thickness of the alluvial deposits in each barrage's watershed along the Nakdong River.

proportion of sand and gravel increased to a maximum of $90 \%$ of the total sediment in the upstream region.

\section{Monitoring Wells and Groundwater Levels}

Increases in the surface water levels because of damming can result in increased groundwater levels in the riparian zones upstream. Based on the groundwater flow direction, topography (derived from GIS analysis), a basic rule of equal spacing for the monitoring wells, economic efficiency, accessibility, and cost, we proposed a total of 900 possible groundwater monitoring sites, comprising 446 automatic stations and 454 manual stations, on the low-lying plains alongside the four major rivers. The purpose of the monitoring stations is to measure the effect of the river water levels on the groundwater levels in the riverside areas and to permit identification of high groundwater levels or groundwater inundation (Kim, 2014). Of the sites suggested, automatic monitoring wells were finally installed at 91 sites alongside the Nakdong River (Fig. 1).

The findings of a previous study indicated that the groundwater levels increased in three regions along the Nakdong River in October 2011 after the barrages were constructed, namely the YeongsanDeoggok Watershed upstream of the Changnyung-Haman Barrage, the Nogok Watershed upstream of the Gangjeong-Koryung Barrage, and the Shincheon-Baekcheon Watershed upstream of the Gangjeong-Koryung Barrage (K-water, 2013). The groundwater levels at the monitoring wells in these two barrage regions increased by, on average, 0.82 , and $2.01 \mathrm{~m}$, respectively. Based on river water level increases of $2.2 \mathrm{~m}$ at the Changnyung-Haman Barrage and $5.8 \mathrm{~m}$ at the Gangjeong-Koryung Barrage (Table 4), the ratios of the groundwater level to the river water level increased by between $35 \%$ and $36 \%$.

Kim et al. (2012) reported an average cross-correlation coefficient of 0.601 between the river water level and the groundwater level in the area upstream of the Changnyung-Haman Barrage, while the coefficient between the rainfall and the groundwater level was much lower at 0.125 . The average cross-correlation coefficient was high in the floodplain adjacent to the river but decreased with distance from the river, reflecting the permeability of the riverside sediments that were between 20 and $40 \mathrm{~m}$ thick and the favorable connectivity between the river and riverside alluvium.

Before a barrage is constructed, the river water levels fluctuated seasonally and were sensitive to rainfall; however, once the barrage is filled with water after a barrage construction, the river water levels 
Table 4. Increases in river water and groundwater levels after barrage construction

\begin{tabular}{|c|c|c|c|c|c|c|c|c|c|}
\hline \multicolumn{2}{|r|}{ Content } & $\begin{array}{l}\text { Changnyung- } \\
\text { Haman B. }\end{array}$ & $\begin{array}{l}\text { Hapcheon- } \\
\text { Changnyung B. }\end{array}$ & $\begin{array}{l}\text { Dalsung } \\
\text { B. }\end{array}$ & $\begin{array}{l}\text { Gangjeong-- } \\
\text { Koryung B. }\end{array}$ & $\begin{array}{l}\text { Chilgok } \\
\text { B. }\end{array}$ & $\begin{array}{l}\text { Gumi } \\
\text { B. }\end{array}$ & $\begin{array}{l}\text { Nakdan } \\
\text { B. }\end{array}$ & $\begin{array}{l}\text { Sangju } \\
\text { B. }\end{array}$ \\
\hline \multirow{3}{*}{ River water level } & $\begin{array}{c}\text { Average water level } \\
\text { before water-filling (a.m.s.l.) }\end{array}$ & 2.3 & 5.6 & 9.9 & 13.7 & 19.5 & 27.2 & 32.6 & 37.1 \\
\hline & $\begin{array}{c}\text { Management level } \\
\text { after water-filling (a.m.s.l.) }\end{array}$ & 4.5 & 10.5 & 14.0 & 19.5 & 25.5 & 32.5 & 40.0 & 47.0 \\
\hline & Rising amount (m) & 2.2 & 4.9 & 4.1 & 5.8 & 6.0 & 5.3 & 7.4 & 9.9 \\
\hline Ground-water level & Average rising amount (m) & 0.82 & 4.23 & - & 2.01 & 1.49 & - & - & - \\
\hline
\end{tabular}

became more stable because they are controlled by the barrage water gate. For example, before filling, the surface water level at the Changnyung-Haman Barrage fluctuated by up to $4 \mathrm{~m}$ depending on whether it was the rainy or dry season; however, after filling, when controlled by the barrage gate, it stabilized and stayed within $2 \mathrm{~m}$. Consequently, when connected to surface water, groundwater levels stabilize when water fills into the riparian areas. Before damming, river water flooding and swampy region in the riversides occurred only during heavy rainfall. However, the duration of high water level gradually increased now because of the water level regulation and damming at the barrage. The area of damp land and the inundation frequency generally increased because of the ongoing shallow groundwater levels and high water levels that resulted from damming.

\section{Groundwater Inundation Vulnerability Index}

Rising groundwater levels can cause soil wetting or inundation of the riverside alluvium, depending on its depth, and can also influence the scale of surface water flooding. The groundwater flooding intensity (GFI) was calculated for each monitoring well from the relationship between the slope of the rising groundwater level $(\tan \alpha)$ and the depth to groundwater $\left(\mathrm{DTW}_{\min }\right)$ for each increase in the level (Sommer and Ullrich, 2005).

$$
\text { Groundwater flooding intensity }=\frac{\tan \propto}{D T W_{\min }} \text {. }
$$

This means that the groundwater inundation may be influenced by the rate of the increase in the groundwater level and the depth to the groundwater. If the groundwater is maintained at a high level for a long time, the soil moisture content will increase and additional increases in the groundwater level will result in more severe inundation conditions. Therefore, the time period over which high groundwater levels are maintained is also important for forecasting and assessing groundwater inundation. We then multiplied the GFI by the duration to obtain the groundwater flooding vulnerability index (FVI) (Fig. 3; Kim et al., 2014). However, because the scales of the duration (T) and GFI (1/L) were different at each monitoring well, we could not compare the inundation susceptibilities of the monitoring wells from the multiplication results; instead, we expressed the final FVI as a standardized value, as follows:

Groundwater inundation vulnerability index $=$

$\frac{\sum_{j=1}^{n}(\text { Standardized duration } \times \text { Standardized GFI })_{j}}{n}$,

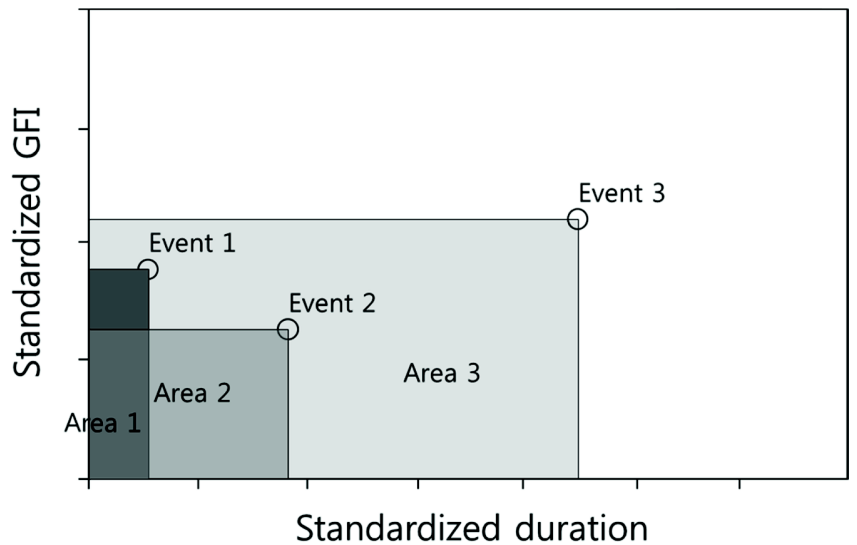

Figure 3. The groundwater flooding vulnerability index calculated using groundwater levels (Kim et al., 2014).

where $n$ is the number of increases in the groundwater level in a time series of groundwater levels.

The high cost involved in installing groundwater monitoring equipment means that it is not practical to install several groundwater monitoring wells in riversides to observe the groundwater levels; we therefore need a tool for forecasting groundwater inundation in unmonitored areas. A model for assessing the possibility of groundwater inundation at non-monitored sites, that is, a site that does not have a groundwater monitoring well, can be developed with discriminant analysis. In this study, we calculated the FVIs for each monitoring well. We also collected continuous data for 11 quantitative and qualitative variables at 61 groundwater monitoring wells (Table 5).

We produced two discriminant functions to explain the FVI, as follows:

$\mathrm{DF}_{1}=0.056 \times \mathrm{V}_{1}+0.479 \times \mathrm{V}_{2}-0.809 \times \mathrm{V}_{3}+0.260 \times \mathrm{V}_{4}+0.283 \times$ $\mathrm{V}_{5}-0.114 \times \mathrm{V}_{6}+0.024 \times \mathrm{V}_{7}-4.889$,

$\mathrm{DF}_{2}=0.160 \times \mathrm{V}_{1}-0.430 \times \mathrm{V}_{2}+0.156 \times \mathrm{V}_{3}+0.889 \times \mathrm{V}_{4}-0.869 \times$ $\mathrm{V}_{5}+0.900 \times \mathrm{V}_{6}+0.166 \times \mathrm{V}_{7}-4.920$,

where $V_{1}$ is the sediment thickness $(m), V_{2}$ is the difference between the land elevation of the monitoring site and the river water level (m), $\mathrm{V}_{3}$ is the difference between the groundwater level and the river water level ( $\mathrm{m}), \mathrm{V}_{4}$ is the type of soil drainage, $\mathrm{V}_{5}$ is the topsoil texture, $\mathrm{V}_{6}$ is the subsoil texture, and $V_{7}$ is the type of hydrological soil feature. The coefficients of the equations indicated that the difference between groundwater level and river water level was the most important factor in discriminant function 1 and that soil features were also important in discriminant function 2 . 
Table 5. Quantitative and qualitative variables used for discriminant analysis (Kim et al., 2015)

\begin{tabular}{|c|c|c|c|c|c|c|}
\hline & Variables & Mean & Minimum & Maximum & St. Deviation & Remark \\
\hline \multirow{7}{*}{$\begin{array}{l}\text { Quantitative } \\
\text { variables }\end{array}$} & Sediment thickness (m) & 18.78 & 5 & 31 & 6.16 & V1 \\
\hline & Land surface elevation (a.m.s.l) & 16.05 & 4.72 & 51.09 & 13.28 & - \\
\hline & Groundwater level (a.m.s.l.) & 12.64 & -0.08 & 46.93 & 12.46 & - \\
\hline & Distance to surface water body $(\mathrm{m})$ & 185.64 & 2 & 802 & 177.2 & - \\
\hline & Depth to groundwater (m) & 4.43 & 1.26 & 10.63 & 2.13 & - \\
\hline & Difference between land elevation and river water level $(\mathrm{m})$ & 3.2 & -0.63 & 11.32 & 2.32 & $\mathrm{~V} 2$ \\
\hline & Difference between groundwater and river water level (m) & -0.21 & -4.53 & 9.68 & 2.05 & V3 \\
\hline \multicolumn{2}{|r|}{ Variables } & Class & \multicolumn{3}{|c|}{ Description } & Remark \\
\hline \multirow{21}{*}{$\begin{array}{l}\text { Qualitative } \\
\text { variables }\end{array}$} & \multirow{6}{*}{ Class of soil drainage } & \multirow{6}{*}{$\begin{array}{c}\text { Class } 1 \\
\text {-Class } 6\end{array}$} & \multicolumn{3}{|c|}{ Class 1: very poorly drained, } & \multirow{6}{*}{ V4 } \\
\hline & & & Class & 2: poorly dra & ained, & \\
\hline & & & Class 3: & veakly poorly & y drained, & \\
\hline & & & Class $4: \mathrm{n}$ & oderately we & ell drained, & \\
\hline & & & Cla & s: well drai & ined, & \\
\hline & & & Class 6: e & xcessively we & ell drained & \\
\hline & \multirow{7}{*}{ Soil texture of top soil } & \multirow{7}{*}{$\begin{array}{c}\text { Class } 2 \\
\text {-Class } 8\end{array}$} & Class & 2: silty clay & loam, & \multirow{7}{*}{ V5 } \\
\hline & & & & ss 3: silty loa & $\mathrm{am}$, & \\
\hline & & & \multicolumn{3}{|c|}{ Class 4: loam, } & \\
\hline & & & \multicolumn{3}{|c|}{ Class 5: sandy loam, } & \\
\hline & & & \multicolumn{3}{|c|}{ Class 6: fine sandy loam, } & \\
\hline & & & \multicolumn{3}{|c|}{ Class 7: loamy sand, } & \\
\hline & & & \multicolumn{3}{|c|}{ Class 8: loamy find sand } & \\
\hline & \multirow{6}{*}{ Soil texture of subsoil } & \multirow{6}{*}{$\begin{array}{c}\text { Class } 1 \\
\text {-Class } 6\end{array}$} & \multicolumn{3}{|c|}{ Class 1: clayey, } & \multirow{6}{*}{ V6 } \\
\hline & & & \multicolumn{3}{|c|}{ Class 2: fine loamy, } & \\
\hline & & & \multicolumn{3}{|c|}{ Class 3: fine silty, } & \\
\hline & & & \multicolumn{3}{|c|}{ Class 4: coarse silty, } & \\
\hline & & & \multicolumn{3}{|c|}{ Class 5: coarse loamy, } & \\
\hline & & & \multicolumn{3}{|c|}{ Class 6: sandy } & \\
\hline & \multirow[t]{2}{*}{ Class of hydrologic soil feature } & \multirow{2}{*}{ Type A-D } & \multicolumn{3}{|c|}{$\begin{array}{c}\text { Definition: minimum rate of infiltration } \\
\text { obtained for bare soil after prolonged } \\
\text { wetting (Classified by the USDA (2005)). }\end{array}$} & \multirow[t]{2}{*}{ V7 } \\
\hline & & & \multicolumn{3}{|c|}{$\begin{array}{c}\text { Infiltration rate: Type A > Type B > } \\
\text { Type C }>\text { Type D }\end{array}$} & \\
\hline
\end{tabular}

We classified the FVIs for 61 of the 91 wells into three types, low, intermediate, and high vulnerability, by plotting the discriminant scores from the above two discriminant functions (Fig. 4). The monitoring data of 30 wells were excluded from the analysis because they had some irregularities, missing values, and showed the effects of pumping. The classification results indicated that this discriminant model was very accurate $(95.3 \%)$ and so was very suitable for assessing the vulnerability of groundwater inundation in the riparian zones of the Nakdong River.

\section{Groundwater Level Estimation}

If the seven input variables needed for the two discriminant models listed above are estimated and collected in the riparian zones, we can assess the vulnerability to groundwater flooding along the Nakdong River with the model described. Soil composition and topographic information can be collected from existing data sources such as government-published digitized soil classification maps and digitized topographic maps. The sediment thickness can be determined from a distribution map kriged with the data from the 1405 points drilled along the Nakdong River. Because the Nakdong River covers a wide area and there are limited monitoring sites, it is difficult to collect or measure groundwater levels, which then means that it is difficult to calculate $V_{3}$, the difference between the groundwater and river water levels, for the whole area.

Before water filling at the barrages, the river water levels fluctuated widely and were sensitive to rainfall, but after filling, they 


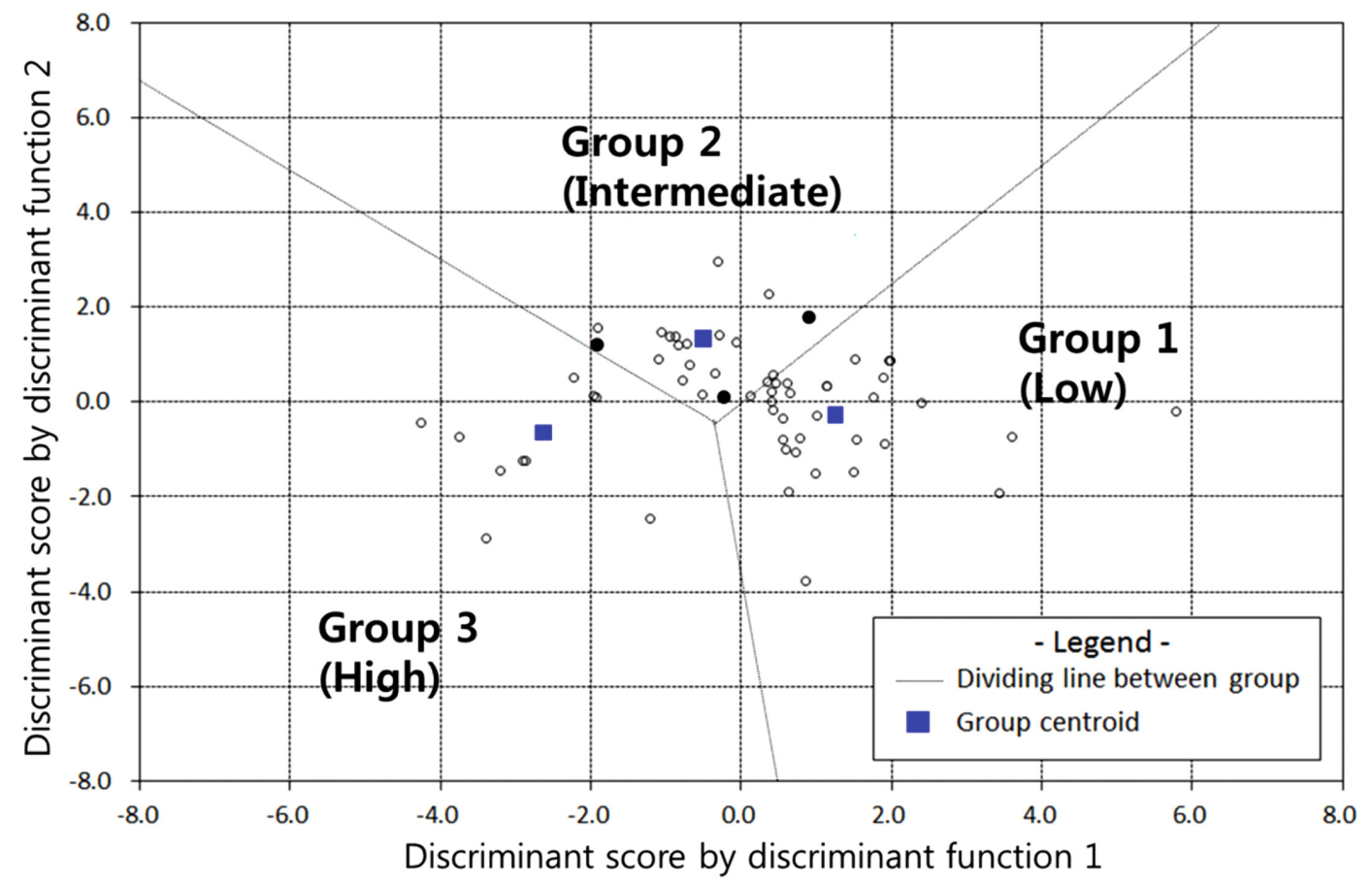

Figure 4. Sixty-one groundwater monitoring wells classified into three groups by the two discriminant functions (closed circles $=$ three wrongly classified monitoring wells) (revised from Kim et al., 2015).

became more stable because they were controlled by the barrage water gates as described above. The high connectivity between the groundwater and river water and the levels' stability after filling indicated that another method could be used to make meaningful estimates of the groundwater level in the flat or gently sloping areas of the riversides. The riverside areas are generally floodplains with either flat topography or very gentle slopes, and so we estimated the groundwater levels from the river water level and the distance from the river, assuming the groundwater level and land surface level were proportional.

We collected groundwater level data from 91 monitoring wells from July 2012 to June 2014 and used the statistical value, mode, to determine the representative groundwater level for each well. We used the mode because the groundwater level histograms were positively skewed at many wells, which reflect how the barrage controls the river water level at a constant level (Fig. 5). We transformed the

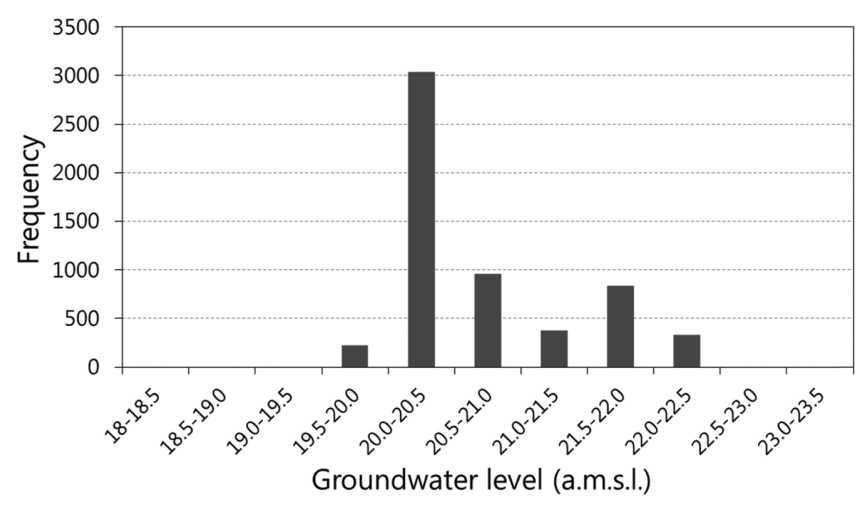

Figure 5. Example of positive skewness in groundwater levels at monitoring well GJM-24 near the Gangjeong Barrage. mode for the groundwater levels at the monitoring sites into a depth to the groundwater level (DTW) by subtracting it from the land elevation at each well site (Table 6). We also examined the relationship between the distance from the bank and the DTW for each monitoring site (Fig. 6). The DTW became gradually smaller as the distance between the monitoring site and river increased. The linear equation for the relationship across the whole Nakdong basin was described by $\mathrm{y}=-0.0006 \mathrm{x}+4.8565$, where $\mathrm{y}$ is DTW (in $\mathrm{m}$ ) and $\mathrm{x}$ is the distance (in $\mathrm{m}$ ) from the river. The difference between the estimated and the actual DTW was quite large, and was up to $5 \mathrm{~m}$, at some sites close to the Nakdong River, which reflects the influence of some artificial activities, such as over-abstraction of groundwater in rice fields, pumping of surface water that affected the groundwater level in small streams or ditches in low-lying land, or irrigation of rice fields. Some wells were in rice fields, where the irregular topography such as the levees around rice fields contributed to deviation of the DTW.

We tested and validated the equation for the DTW in a small basin in the middle reaches of the Nakdong River, close to the GangjeongKoryeong Barrage by using a numerical model and field data (Fig. 7). A numerical model developed using MOD-FLOW has been used to estimate the groundwater levels which can be produced by a damming at the barrage (Kim, 2014). The model used a digitized topographic map with a scale of 1:5,000 and its boundary was simply determined based on the topographic boundary. The grid size of the model was generally $25 \times 25 \mathrm{~m}$ or smaller. Groundwater recharge rate, about $12.4 \%$, was estimated using the WTF (Water table fluctuation) method (Healy and Cook, 2002). Data from 45 field measurements by Lugeon tests, injection tests, and pumping tests at the drilling wells were used to estimate the representative hydraulic conductivity and determine lateral and vertical composition at each layer in the model. The hydraulic conductivities were $2.33 \times 10^{-4}$ to $1.47 \times 10^{-2} \mathrm{~cm} / \mathrm{s}$ for alluvial sedi- 
Table 6. Estimation of groundwater levels along the Nakdong River

\begin{tabular}{|c|c|c|c|c|c|}
\hline Barrage & Monitoring well & $\begin{array}{l}\text { Mode of groundwater } \\
\text { levels (El. m) }\end{array}$ & $\begin{array}{l}\text { Elevation of monitoring } \\
\text { site (El. m) }\end{array}$ & $\begin{array}{l}\text { Depth to groundwater at } \\
\text { monitoring site (DTW, m) }\end{array}$ & $\begin{array}{l}\text { Distance from } \\
\text { bank }(\mathrm{m})\end{array}$ \\
\hline \multirow{4}{*}{ Sangju } & SJM-001 & 35.6 & 46.09 & 10.49 & 38 \\
\hline & SJM-003 & 45.8 & 50.45 & 4.65 & 113 \\
\hline & SJM-009 & 45.8 & 51.655 & 5.86 & 0 \\
\hline & SJM-010 & 47.1 & 50.495 & 3.40 & 53 \\
\hline \multirow{3}{*}{ Nakdan } & NDM-001 & 32.3 & 41.17 & 8.87 & 218 \\
\hline & NDM-004 & 40.1 & 42.92 & 2.82 & 53 \\
\hline & NDM-008 & 40.0 & 47.59 & 7.59 & 0 \\
\hline \multirow{4}{*}{ Gumi } & GMM-002 & 37.9 & 37.615 & 0.00 & 384 \\
\hline & GMM-004 & 33.2 & 38.39 & 5.19 & 33 \\
\hline & GMM-005 & 32.1 & 36.29 & 4.19 & 151 \\
\hline & GMM-006 & 31.4 & 35.545 & 4.15 & 404 \\
\hline \multirow{8}{*}{ Chilgok } & CGM-001 & 19.5 & 28.575 & 9.08 & 113 \\
\hline & CGM-003 & 24.0 & 27.845 & 3.85 & 52 \\
\hline & CGM-005 & 24.8 & 28.75 & 3.95 & 38 \\
\hline & CGM-007 & 24.8 & 30.41 & 5.61 & 179 \\
\hline & CGM-012 & 25.0 & 30.28 & 5.28 & 26 \\
\hline & CGM-015 & 25.1 & 30.815 & 5.72 & 25 \\
\hline & CGM-022 & 26.4 & 28.73 & 2.33 & 543 \\
\hline & CGM-023 & 26.0 & 33.45 & 7.45 & 32 \\
\hline \multirow{8}{*}{$\begin{array}{l}\text { Gangjeong- } \\
\text { Koryeong }\end{array}$} & GJM-001 & 19.8 & 21.485 & 1.69 & 394 \\
\hline & GJM-004 & 20.2 & 21.12 & 0.92 & 8 \\
\hline & GJM-005 & 20.8 & 24.555 & 3.76 & 23 \\
\hline & GJM-008 & 20.7 & 25.545 & 4.85 & 18 \\
\hline & GJM-013 & 18.2 & 19.815 & 1.62 & 267 \\
\hline & GJM-014 & 16.6 & 19.47 & 2.87 & 627 \\
\hline & GJM-016 & 17.6 & 20.84 & 3.24 & 697 \\
\hline & GJM-017 & 18.1 & 22.3 & 4.20 & 1,660 \\
\hline \multirow{4}{*}{ Dalsung } & DSM-006 & 17.0 & 20.085 & 3.09 & 42 \\
\hline & DSM-017 & 15.4 & 18.445 & 3.05 & 29 \\
\hline & DSM-020 & 15.2 & 20.845 & 5.65 & 35 \\
\hline & DSM-027 & 14.3 & 21.61 & 7.31 & 16 \\
\hline \multirow{2}{*}{$\begin{array}{l}\text { Hapcheon- } \\
\text { Changnyeong }\end{array}$} & HCM-007 & 12.5 & 15.24 & 2.74 & 887 \\
\hline & HCM-017 & 10.1 & 13.165 & 3.07 & 1,340 \\
\hline \multirow{8}{*}{$\begin{array}{c}\text { Changnyeong } \\
\text {-Haman }\end{array}$} & HAM-002 & 0.5 & 10.55 & 10.05 & 223 \\
\hline & HAM-004 & 4.9 & 12.63 & 7.73 & 32 \\
\hline & HAM-005 & 6.4 & 8.5 & 2.10 & 904 \\
\hline & HAM-007 & 7.6 & 8.88 & 1.28 & 30 \\
\hline & HAM-010 & 5.5 & 10.26 & 4.76 & 70 \\
\hline & HAM-011 & 6.0 & 7.29 & 1.29 & 1,260 \\
\hline & HAM-013 & 9.4 & 10.955 & 1.56 & 3,100 \\
\hline & HAM-014 & 3.1 & 6.05 & 2.95 & 961 \\
\hline
\end{tabular}


Table 6. (continued)

\begin{tabular}{|c|c|c|c|c|c|}
\hline Barrage & Monitoring well & $\begin{array}{l}\text { Mode of groundwater } \\
\text { levels (El. m) }\end{array}$ & $\begin{array}{l}\text { Elevation of monitoring } \\
\text { site (El. m) }\end{array}$ & $\begin{array}{l}\text { Depth to groundwater at } \\
\text { monitoring site (DTW, m) }\end{array}$ & $\begin{array}{l}\text { Distance from } \\
\text { bank }(m)\end{array}$ \\
\hline \multirow{41}{*}{$\begin{array}{l}\text { Changnyeong } \\
\text {-Haman }\end{array}$} & HAM-015 & 5.8 & 7.817 & 2.02 & 2,030 \\
\hline & НАМ-019 & 3.7 & 11.91 & 8.21 & 29 \\
\hline & HAM-021 & 1.6 & 6.925 & 5.33 & 996 \\
\hline & HAM-022 & 4.8 & 11.11 & 6.31 & 1,330 \\
\hline & HAM-025 & 3.4 & 9.17 & 5.77 & 3,440 \\
\hline & HAM-026 & 4.7 & 7.77 & 3.07 & 3,670 \\
\hline & HAM-027 & 4.5 & 6.385 & 1.89 & 3,840 \\
\hline & HAM-028 & 7.7 & 9.72 & 2.02 & 5,650 \\
\hline & HAM-030 & 9.0 & 10.625 & 1.63 & 5,770 \\
\hline & HAM-035 & 1.5 & 6.76 & 5.26 & 1,640 \\
\hline & HAM-038 & 6.3 & 11.3 & 5.00 & 421 \\
\hline & HAM-040 & 5.0 & 10.63 & 5.63 & 424 \\
\hline & HAM-041 & 5.1 & 10.795 & 5.70 & 175 \\
\hline & HAM-042 & 5.3 & 9.7 & 4.40 & 1,040 \\
\hline & HAM-045 & 4.3 & 5.42 & 1.12 & 1,750 \\
\hline & HAM-046 & 4.9 & 8.87 & 3.97 & 2,350 \\
\hline & HAM-047 & 5.3 & 9.095 & 3.80 & 2,410 \\
\hline & HAM-048 & 5.5 & 6.71 & 1.21 & 3,320 \\
\hline & HAM-051 & 7.4 & 9.46 & 2.06 & 5,260 \\
\hline & HAM-056 & 5.0 & 11.2 & 6.20 & 123 \\
\hline & HAM-059 & 5.7 & 8.48 & 2.78 & 354 \\
\hline & HAM-060 & 5.0 & 9.23 & 4.23 & 168 \\
\hline & HAM-061 & 5.2 & 10.08 & 4.88 & 771 \\
\hline & HAM-062 & 5.6 & 7.41 & 1.81 & 2,230 \\
\hline & HAM-063 & 5.2 & 7.99 & 2.79 & 2,880 \\
\hline & HAM-064 & 4.8 & 9.7 & 4.90 & 2,140 \\
\hline & HAM-065 & 6.1 & 11.84 & 5.74 & 500 \\
\hline & HAM-071 & 3.7 & 7.77 & 4.07 & 644 \\
\hline & HAM-072 & 4.7 & 7.525 & 2.83 & 62 \\
\hline & HAM-073 & 4.5 & 9.465 & 4.97 & 274 \\
\hline & HAM-074 & 2.6 & 7.83 & 5.23 & 1,930 \\
\hline & HAM-075 & 4.5 & 9.25 & 4.75 & 2,470 \\
\hline & HAM-078 & 3.6 & 7.06 & 3.46 & 2,300 \\
\hline & HAM-081 & 4.9 & 6.74 & 1.84 & 4,510 \\
\hline & HAM-086 & 5.0 & 7.41 & 2.41 & 3,830 \\
\hline & HAM-087 & 4.2 & 8.17 & 3.97 & 3,790 \\
\hline & HAM-088 & 5.8 & 7.61 & 1.81 & 4,110 \\
\hline & HAM-089 & 6.8 & 9.11 & 2.31 & 4,610 \\
\hline & HAM-090 & 5.9 & 7.285 & 1.39 & 4,890 \\
\hline & HAM-091 & 5.4 & 7.84 & 2.44 & 5,420 \\
\hline & HAM-092 & 6.7 & 7.99 & 1.29 & 1,280 \\
\hline
\end{tabular}




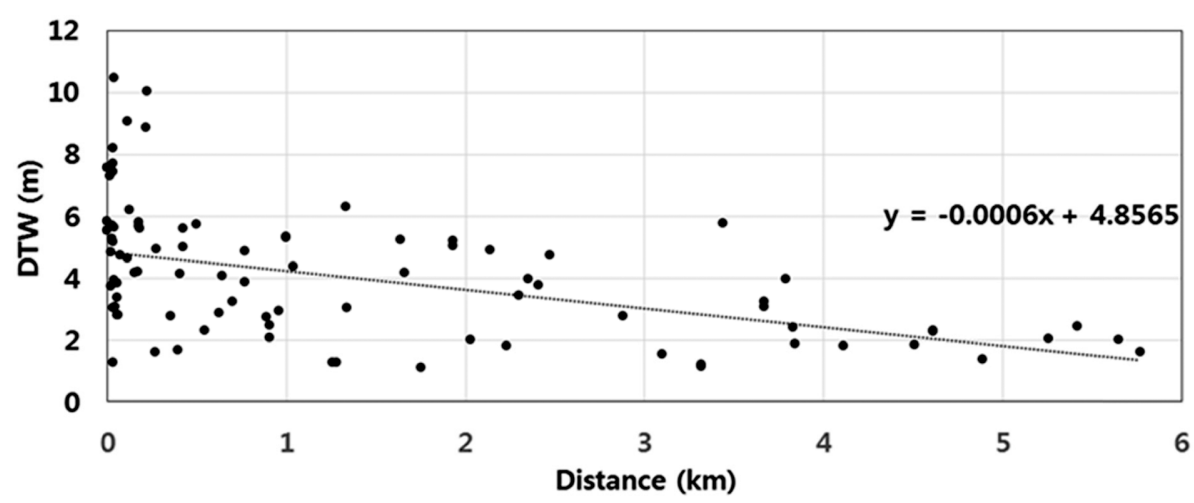

Figure 6. Relationship between DTW (depth to groundwater level) and the distance from the river at groundwater monitoring sites in the Nakdong Watershed. ments (layer 1), and $8.44 \times 10^{-6}$ to $2.31 \times 10^{-4}$ $\mathrm{cm} / \mathrm{s}$ for bedrock (layer 2). The steady-state model was simulated under the conditions of the 5-year average river level before barrage construction, drainage levels, and groundwater pumping rates. Groundwater levels were adjusted step by step to produce a best fitted model through the calibration of geologic layer distribution and hydraulic conductivity (Fig. 8a).

Under the assumption that river levels will increase up to the managed level after barrage construction and will not be fluctuated, the transient model was constructed in order to
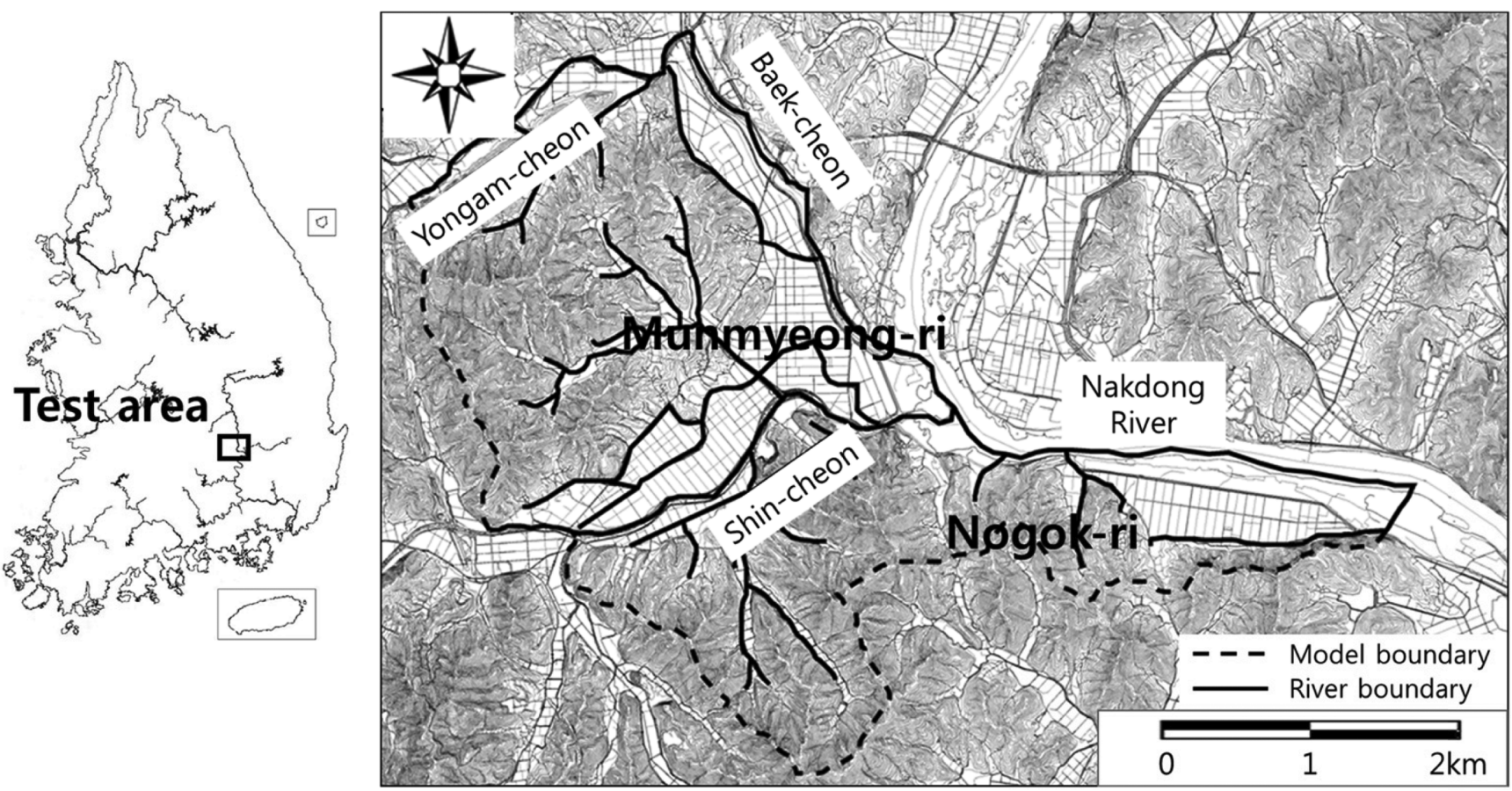

Figure 7. Location of the test sites in the middle reaches of the Nakdong River.
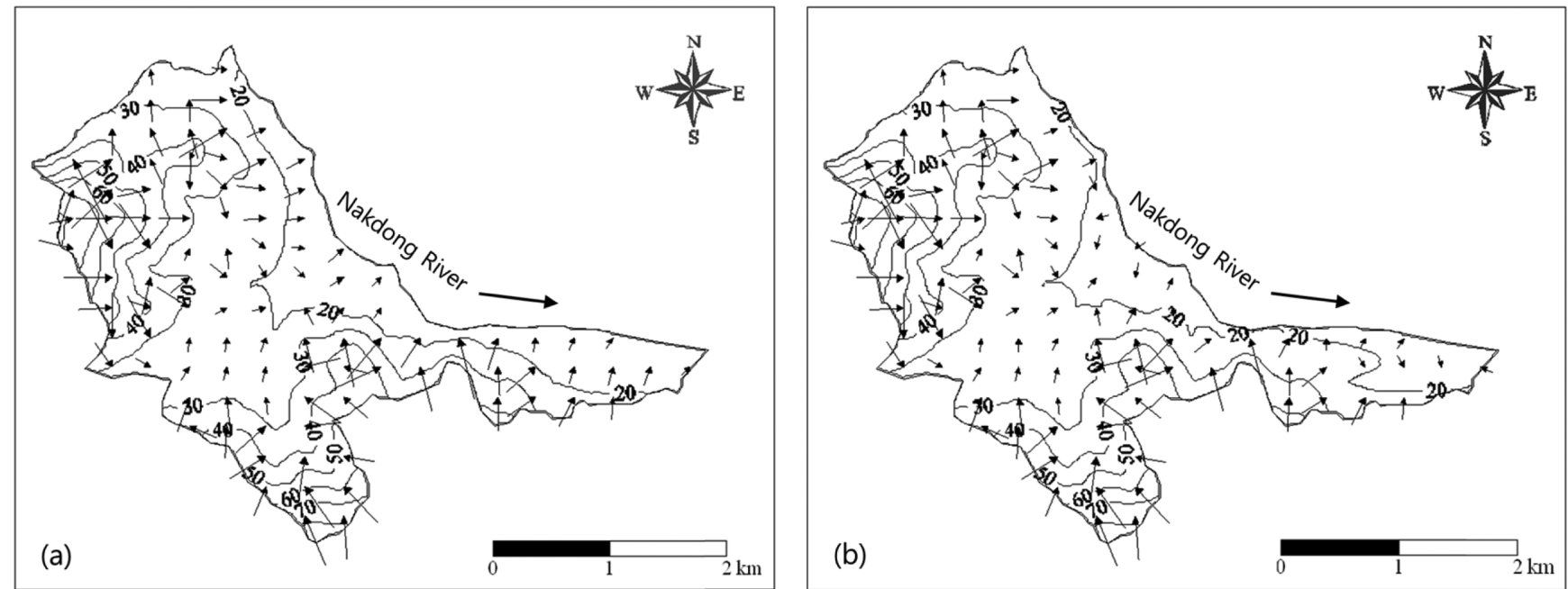

Figure 8. Groundwater level and flow by a numerical model. (a) steady-state model, (b) transient model (Kim, 2014). 
assess groundwater flow and a possibility of inundation in the riverside after a damming at the barrage (Fig. 8b). Depth to groundwater level shallower than $1 \mathrm{~m}$ was finally estimated by this model (Fig. 9). This shallow groundwater level means that high soil moisture content in the uppermost sediments is easy to be made during a rainfall and consequently produce a swamp or inundation. A cross-section of groundwater levels along $\mathrm{A}-\mathrm{A}^{\prime}$ line is drawn and compared with the actual groundwater levels and the result of linear regression model (Fig. 10). Groundwater level of a numerical model is similar to that of linear regression model in the plain area, especially from 1 to $300 \mathrm{~m}$,

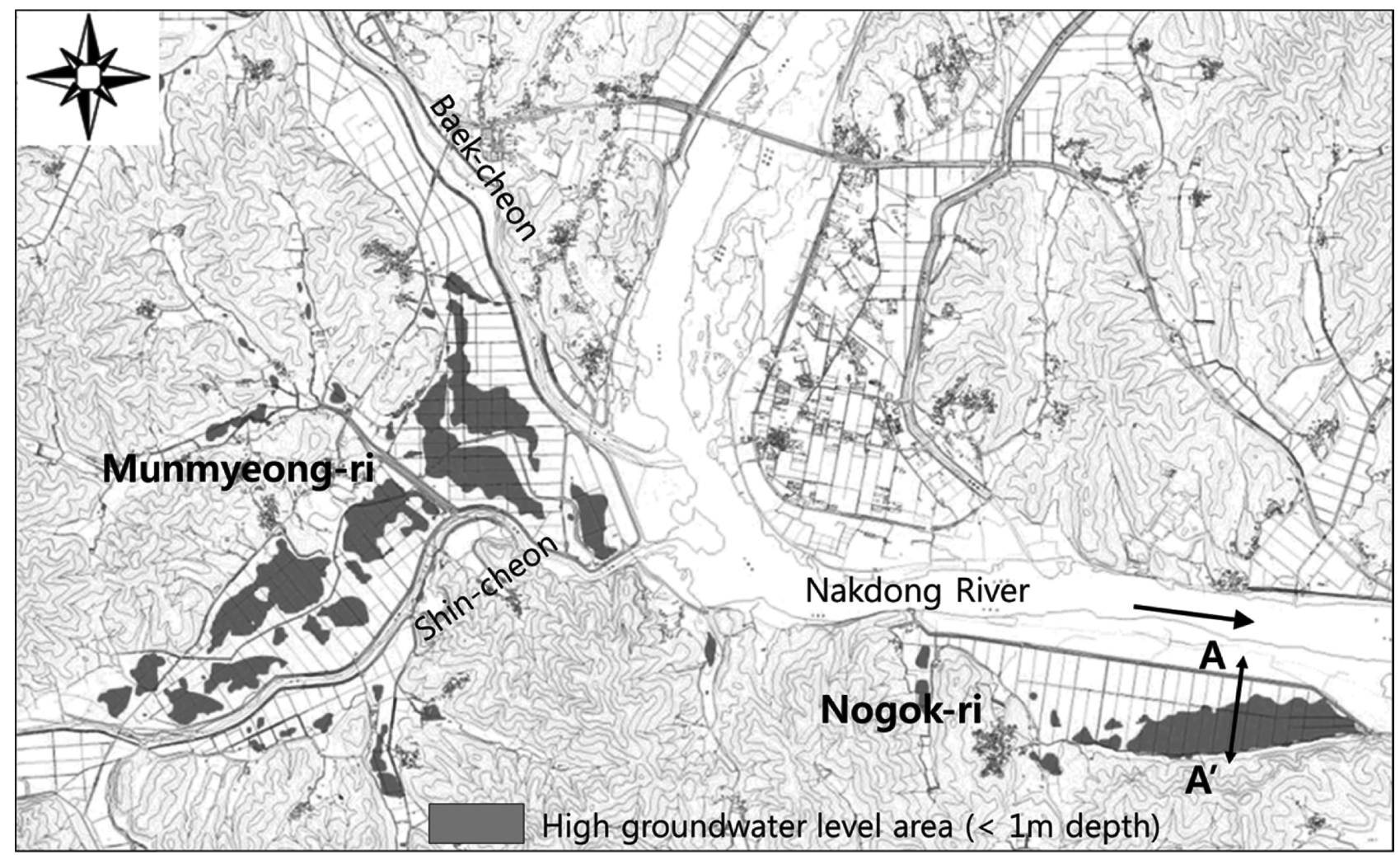

Figure 9. Distribution map of groundwater level depth shallower than 1 m (modified from Kim, 2014).

A

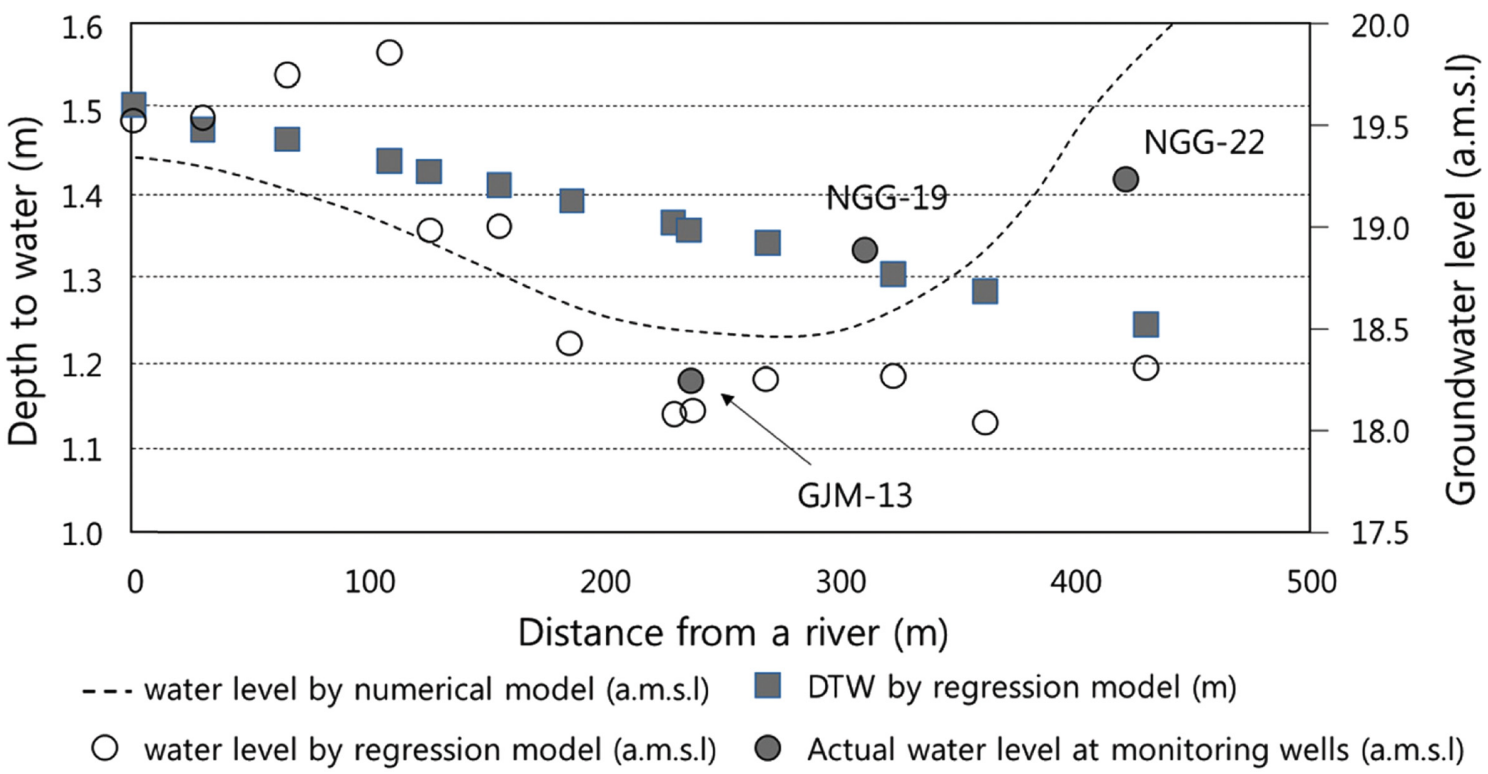

Figure 10. Estimated groundwater levels in a test site (Nogok-ri) in the middle reaches of the Nakdong River and the actual groundwater levels at three wells. 
close to a river. In the area close to the southern mountain the difference between them reaches $1.5 \mathrm{~m}$, which is because groundwater flow discharged from the mountain is dominant. Besides the modeling result, the result estimated by a linear regression model is also compared to the actual data, which is measured at three wells, GJM-13, NGG-19, and NGG-22 (Fig. 10). The estimated DTW tended to decrease as the distance increased. The mode of the actual groundwater level time series for two years at the monitoring site, GJM-13, was 18.20 El.m and the estimated value was $18.08 \mathrm{El} . \mathrm{m}$, so the difference was only $12 \mathrm{~cm}$. The other manual measurement sites, NGG-19 and NGG-22, also show a similar trend of groundwater level's change in the basin. These results show that the linear equation for estimating the groundwater level could be used in a regional model on a flat riverside plain where the groundwater level was not strongly affected by artificial activities or discharge from higher area.

\section{Determination of the Optimum Grid Size}

Regional groundwater inundation susceptibility maps are based on grids and it means that each cell needs to be assigned a representative FVI value. We needed the optimum grid size to draw the map that best represented the site characteristics on a regional map. We directly obtained values of the three variables, $V_{1}, V_{2}$, and $V_{3}$, at any point on their distribution maps because they are really a type of equipotential map.

However, the distribution maps of the other four variables, $V_{4}, V_{5}$, $V_{6}$, and $V_{7}$, are not equipotential maps, but are areal or irregular polygon-shaped distribution maps. Representative values to explain properly the site features needs to be selected on the maps at these variables. The values at any point may be different according to the point location at the maps and therefore the optimum grid size needs to be deter- mined. For example, the distribution of soil drainage is not a regular quadrilateral but is very irregularly shaped and may be arborescent-, elliptical-, or oblong-shaped because of different drainage types.

A grid system is introduced to simplify this irregular areal distribution. We calculated the area of each variable for the whole region along the Nakdong River with ArcGIS, and the areas calculated for the four variables are shown in Table 7. The class means the areal range of each variable, which is converted into a regular quadrilateral. For example, when the soil texture of the topsoil is between 0 and $50 \mathrm{~m}$, the length of one side of a regular quadrilateral is between 0 and $50 \mathrm{~m}$. The frequency is the total number of that class across the entire riverside region. As shown in Table 7, the increase in the frequency was greatest for the class from 100 to $150 \mathrm{~m}$. We therefore used this as a representative grid size because the frequency either changed or decreased just after 100 or $150 \mathrm{~m}$. Consequently, to simplify the process of mapping the riparian zones of the Nakdong River, we used $100 \mathrm{~m}$ as the optimum length of a grid unit as about $70 \%$ of the cells for the four variables belonged to this size. Private lands of rice or dry fields, which had actual unit area sizes of between 50 and $150 \mathrm{~m}$ in this country, were generally related to soil or land use types. The actual lengths of the fields confirm that the proposed length of $100 \mathrm{~m}$ was an appropriate representative value.

\section{Mapping the Groundwater Inundation Vulner- ability alongside the Nakdong River}

We used digitized maps in ArcGIS to produce representative values of the seven variables for each point of the $100 \times 100 \mathrm{~m}$ grid and calculated $D F_{1}$ and $D F_{2}$ at 33,264 points along the Nakdong River. We then reclassified the points into three levels of vulnerability of groundwater inundation, namely low (= safe from inundation), inter-

Table 7. Frequencies of the quadrilateral grid size for four variables, namely (a) soil drainage, (b) soil texture of top soil, (c) soil texture of subsoil, and (d) hydraulic soil feature

\begin{tabular}{|c|c|c|c|c|c|c|c|c|}
\hline \multirow{2}{*}{ Range of grid size (m) } & \multicolumn{2}{|c|}{ Soil texture of top soil } & \multicolumn{2}{|c|}{ Soil texture of subsoil } & \multicolumn{2}{|c|}{ Soil drainage } & \multicolumn{2}{|c|}{ Hydraulic soil feature } \\
\hline & No. & Differences & No. & Differences & No. & Differences & No. & Differences \\
\hline $0-50$ & 1234 & & 1141 & & 2018 & & 1622 & \\
\hline $50-100$ & 978 & 256 & 957 & 184 & 1620 & 398 & 1209 & 413 \\
\hline $100-150$ & 670 & 308 & 748 & 209 & 1028 & 592 & 678 & 531 \\
\hline $150-200$ & 439 & 231 & 431 & 317 & 622 & 406 & 417 & 261 \\
\hline $200-250$ & 297 & 142 & 295 & 136 & 386 & 236 & 246 & 171 \\
\hline $250-300$ & 199 & 98 & 200 & 95 & 259 & 127 & 171 & 75 \\
\hline $300-350$ & 131 & 68 & 163 & 37 & 189 & 70 & 129 & 42 \\
\hline $350-400$ & 109 & 22 & 129 & 34 & 124 & 65 & 94 & 35 \\
\hline $400-450$ & 73 & 36 & 82 & 47 & 98 & 26 & 71 & 23 \\
\hline $450-500$ & 55 & 18 & 58 & 24 & 79 & 19 & 57 & 14 \\
\hline $500-550$ & 60 & -5 & 60 & -2 & 65 & 14 & 50 & 7 \\
\hline $550-600$ & 50 & 10 & 50 & 10 & 45 & 20 & 33 & 17 \\
\hline $600-650$ & 41 & 9 & 43 & 7 & 40 & 5 & 36 & -3 \\
\hline $650-700$ & 33 & 8 & 36 & 7 & 30 & 10 & 28 & 8 \\
\hline
\end{tabular}




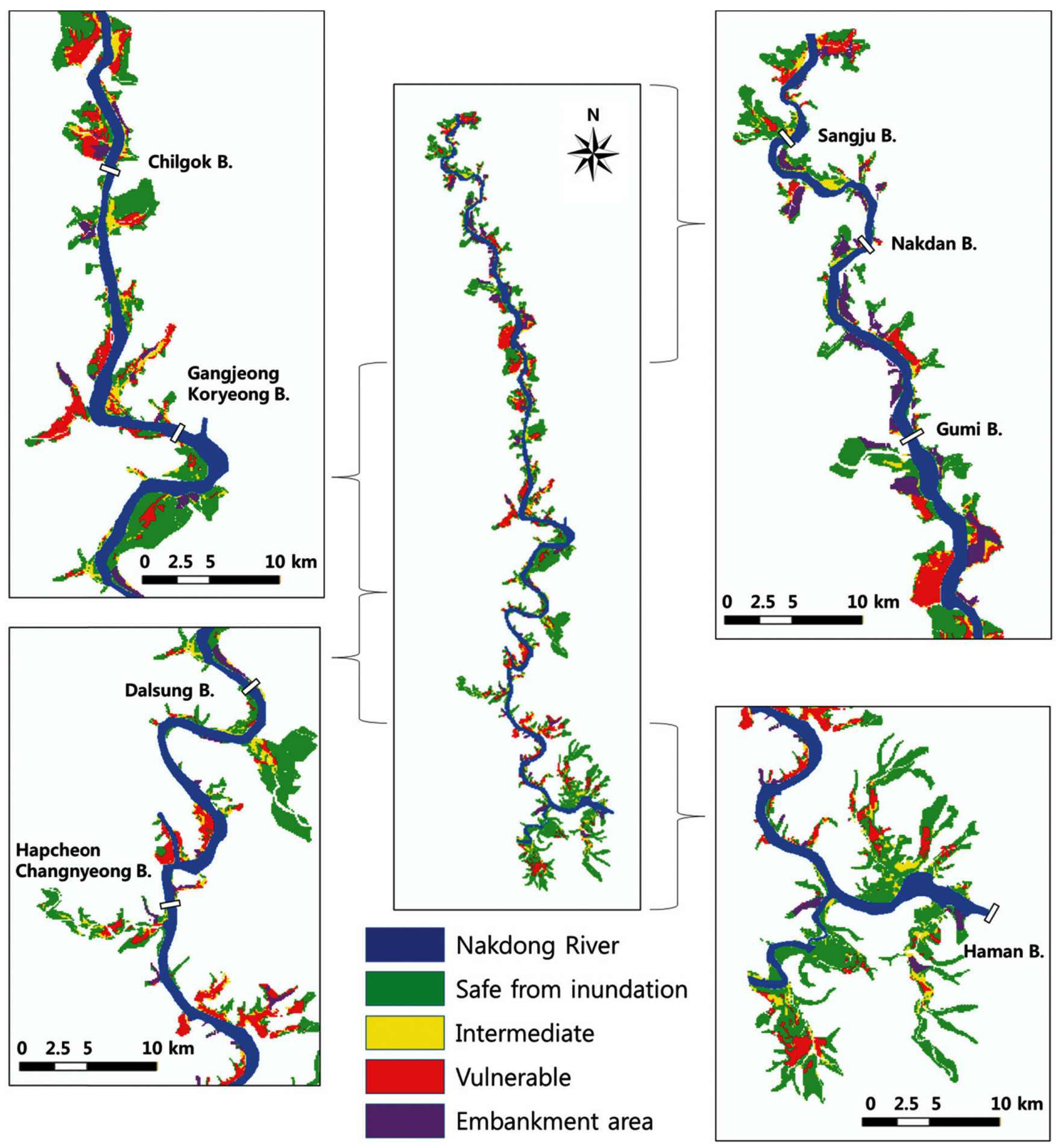

Figure 11. Groundwater flooding susceptibility map of the Nakdong River (red = vulnerable; yellow = intermediate; green = safe from inundation; violet = embankment area).

mediate, and high (= vulnerable) (Fig. 11). We had an additional classification, which was an embanked area in the low lands, where the farmland terrain had been elevated by filling with soil during the Four Rivers Restoration Project. This region previously would have been classified as having high vulnerability to inundation but, after satisfactory embankment, it was no longer susceptible.

The statistics for the groundwater inundation susceptibility types for each barrage watershed are shown in Figure 12. The areas with high vulnerability in the watersheds of the Changnyeong-Haman, Chilgok, and Gangjeong-Koryung barrages were relatively large and covered 2152,1870 , and 1066 grids, or, when converted to an area, 21.5, 18.7, and $10.7 \mathrm{~km}^{2}$, respectively, if there is no artificial drawdown of groundwater levels. At the Chilgok, Gangjeong-Koryung, and Sangju barrages, $28.9 \%, 28.2 \%$, and $27.6 \%$ of the watersheds were classified as high 


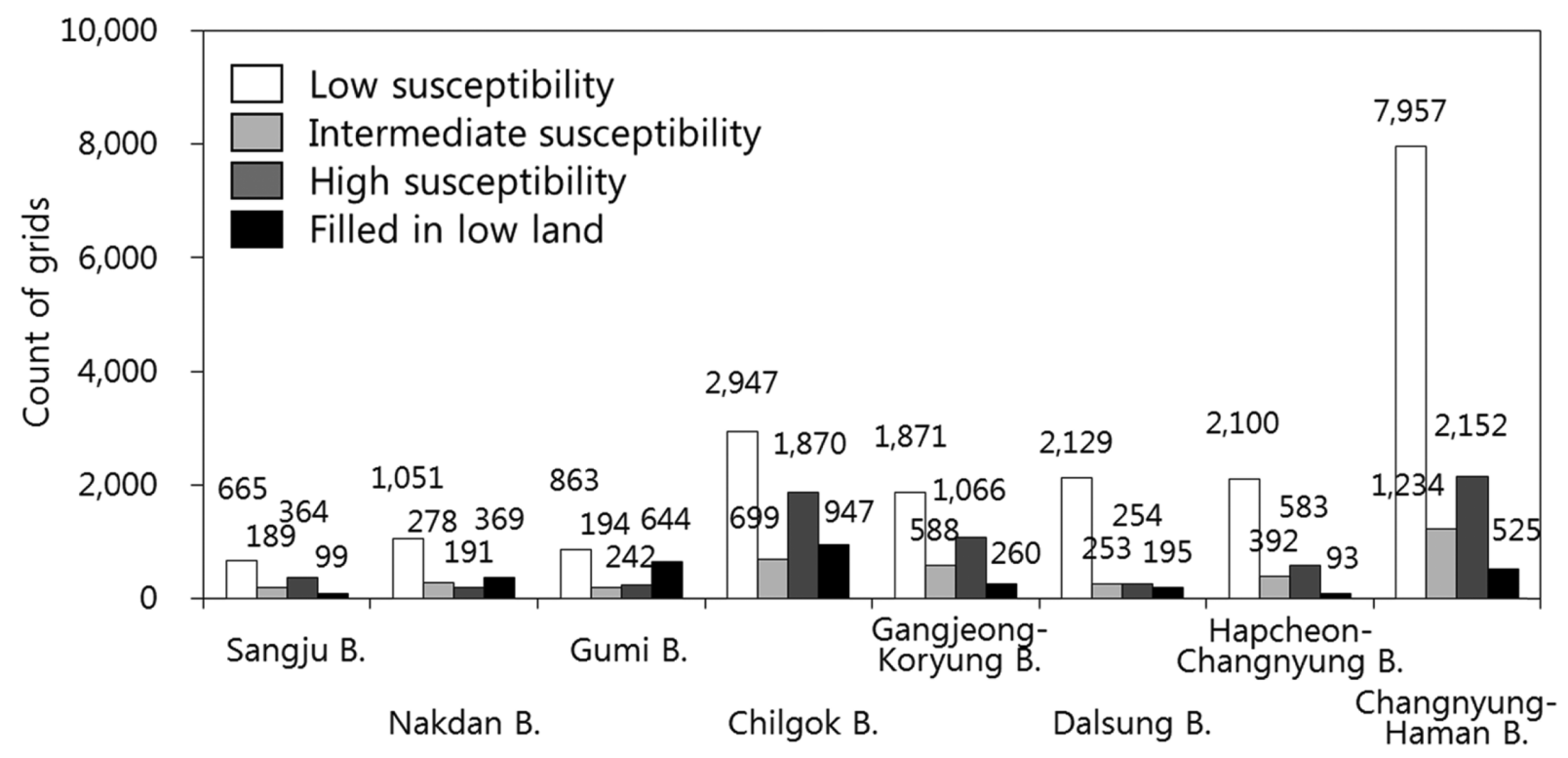

Figure 12. Histograms of the distribution of groundwater flooding susceptibility for each barrage watershed.

vulnerability.

The river system of the Changnyeong-Haman Barrage, including the tributaries of the Nakdong River, is described as arborescent. Before the barrage was constructed, this area was dominated by low lands and many wetlands or damp regions formed near the alluvial fan or on the flat plain where steep hills met the flat flood plain. These regions have always had shallow groundwater levels because of concentrated water flow from the hills and have historically experienced frequent surface water flooding during seasons of heavy rain. The groundwater inundation susceptibility map also properly reflects the existing flooding or swampy conditions at places where steep hills meet the flat plain.

Upstream of the Gangjeong-Koryeong and Chilgok barrages, large alluvial flat basins where multiple tributaries merge with the Nakdong River have developed because of the low elevation land, and so a large area is vulnerable to groundwater inundation. In contrast, upstream of the Dalseong and Hapcheon-Changnyung barrages, the area of high vulnerability is relatively small; this area comprises small basins that run parallel to the river, and the Nakdong River flows along a relatively narrow valley that reflects the regional geological structure or rock type.

The other watersheds do not have any distinct arborescent streams and the basins are mostly distributed parallel to the Nakdong River. High vulnerability regions are only found where the terrain elevation is low, close to the Nakdong River, or where small streams meet in the basins.

To verify the map, we carried out a field survey of flooding or swampy conditions during the non-rainy season from March to April, after the barrages were constructed and when no water was used for irrigation (Fig. 13). We carried out a visual inspection of the land condition in six areas. The grey color in Figure 13 indicates a rice field or greenhouse with swampy or wet conditions. While the visual inspection might have been somewhat inaccurate and subjective, the distributions of the areas identified as wet or swampy during the field survey were similar to those on the susceptibility map. Additionally, distribution map of groundwater level depth, shallower than $1 \mathrm{~m}$, drawn for Munmyeong-ri and Nogok-ri in Figure 9 indicates that the area with a possibility of swamp or inundation proposed by a numerical model is similar to that by a regression model in Figures $13 \mathrm{~d}$ and e.

\section{Discussion and Conclusions}

Hydraulically connected systems occur when the groundwater level has physical contact with the river bed and there is water exchange between them. The difference in elevation and interactions between them may change when new barrages and reservoirs are constructed.

When a barrage is constructed, surface water can be stored in the upper reservoir, resulting in an increase in both the groundwater and surface water levels because of the hydraulic connection generally found between groundwater and river water on riverbanks or beside a river. In recent years, 16 large barrages have been constructed in South Korea. Before they were constructed, many aspects, including safety, design, and efficiency, were considered to ensure the structures were economically and environment-friendly. However, new huge engineering projects can give rise to various unexpected problems, one of which is groundwater inundation because of high water levels. Low elevation land is always exposed to flooding and an increase in the river water level caused by construction of a barrage can aggravate this situation. Therefore, the groundwater level in the riverside area should be considered when designing schemes to control the river water level with a water gate, especially during the rainy season.

We used seven input variables to develop a discriminant model that shows the risk of groundwater inundation caused by changes in the river water level. We compiled a groundwater inundation vulnerability map and confirmed its validity by checking the similarity between the highly susceptible areas and the actual swampy field conditions or 

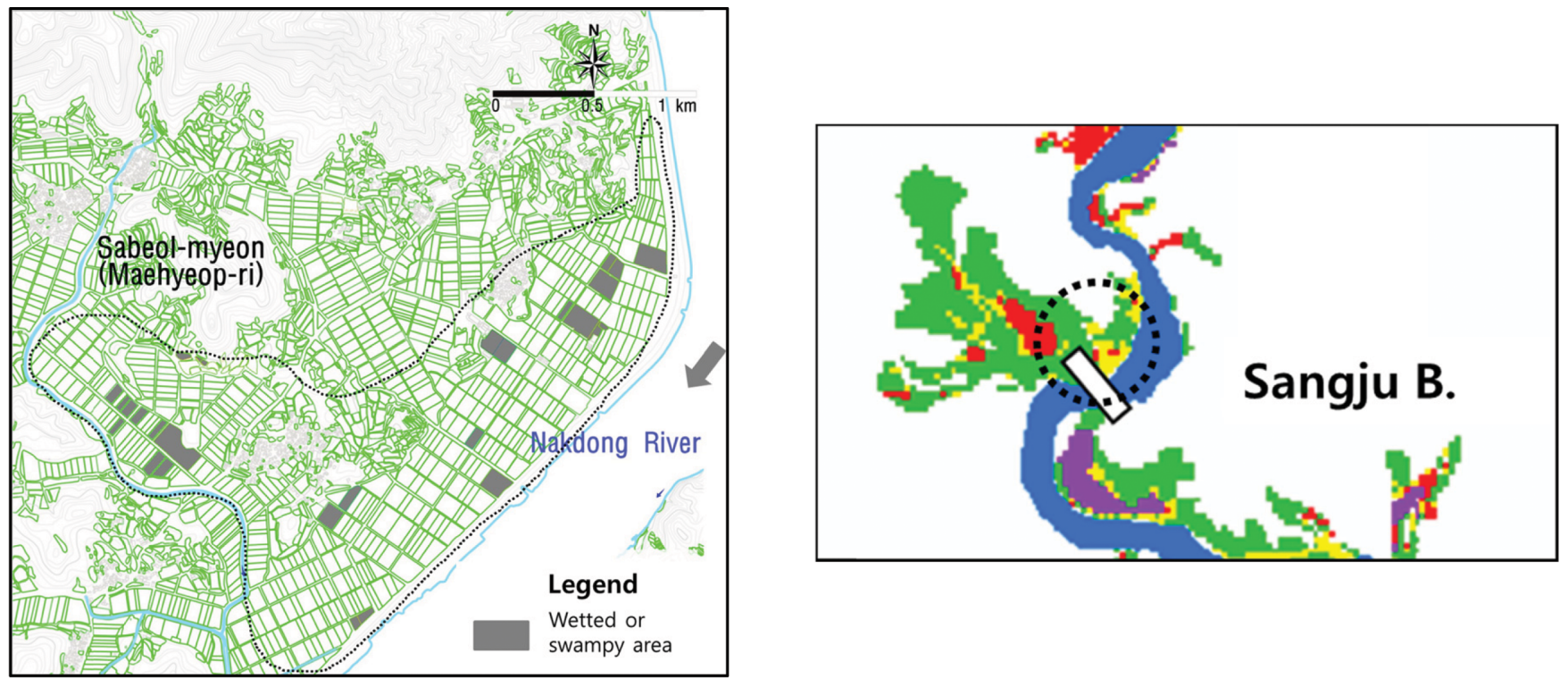

(a) Maehyeop-ri area
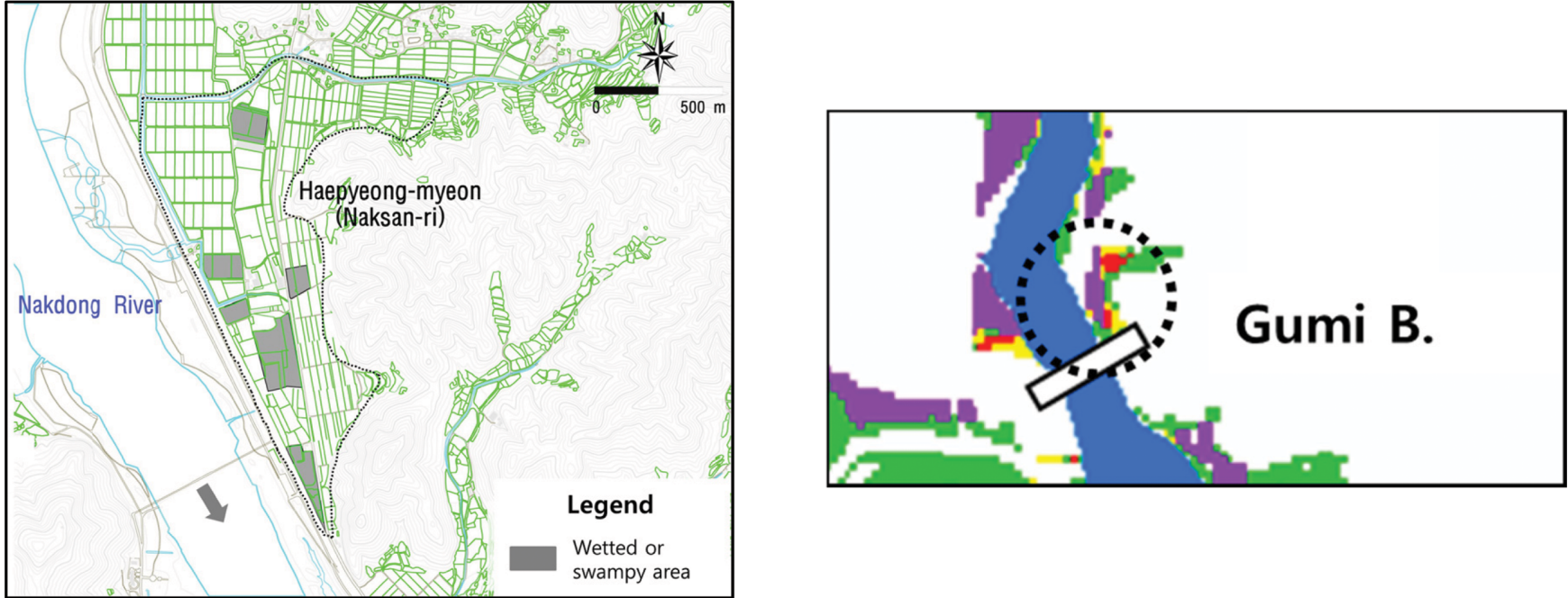

(b) Naksan-ri area
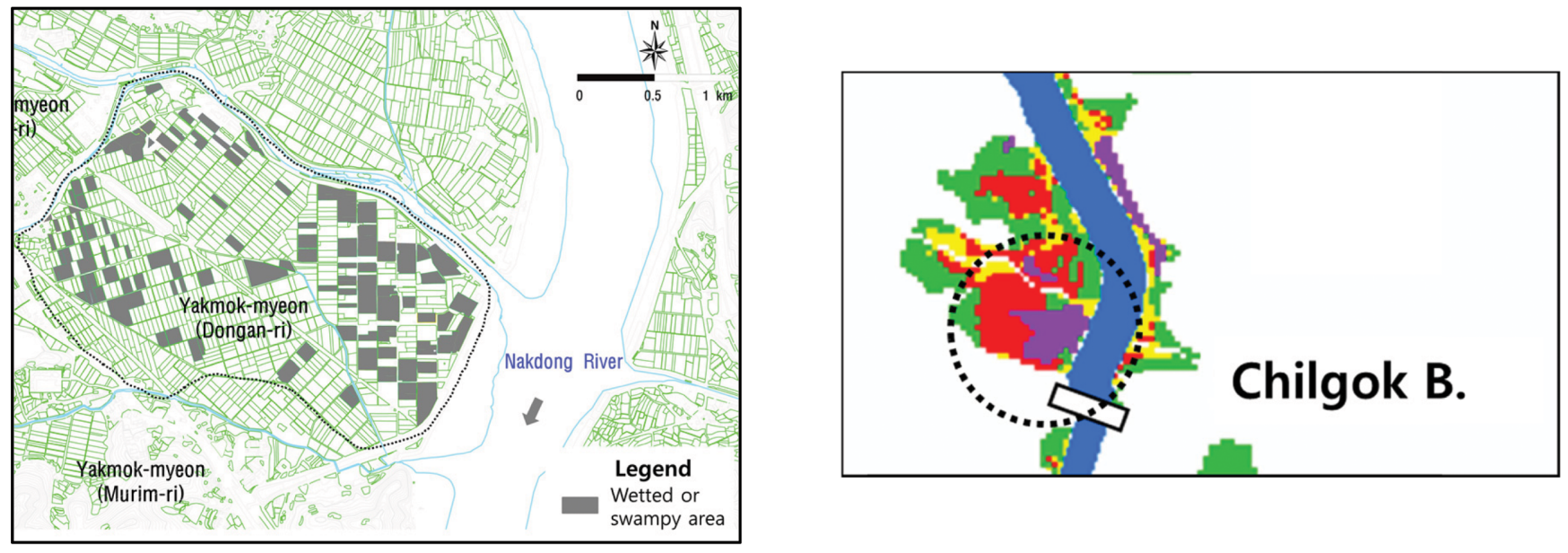

(c) Dongan-ri area

Figure 13. Results from field surveys of swampy areas at six sites upstream of the barrages and their locations (circled areas) in the groundwater flooding susceptibility map. 


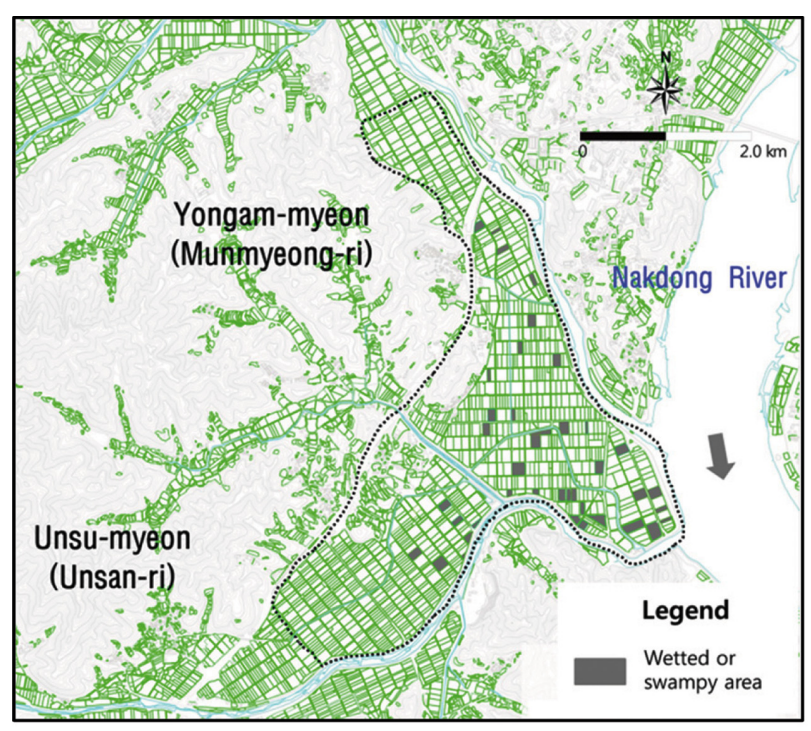

(d) Munmyeong-ri area

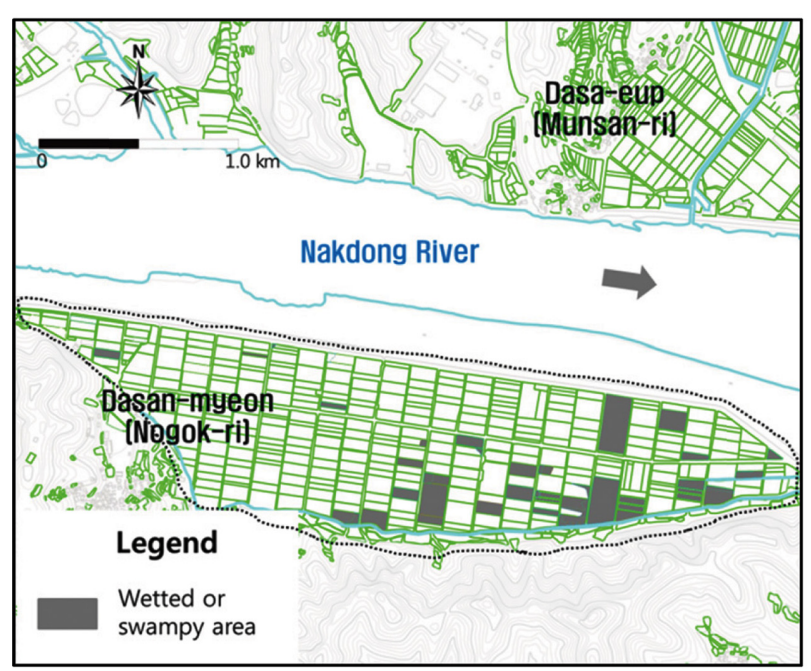

(e) Nogok-ri area

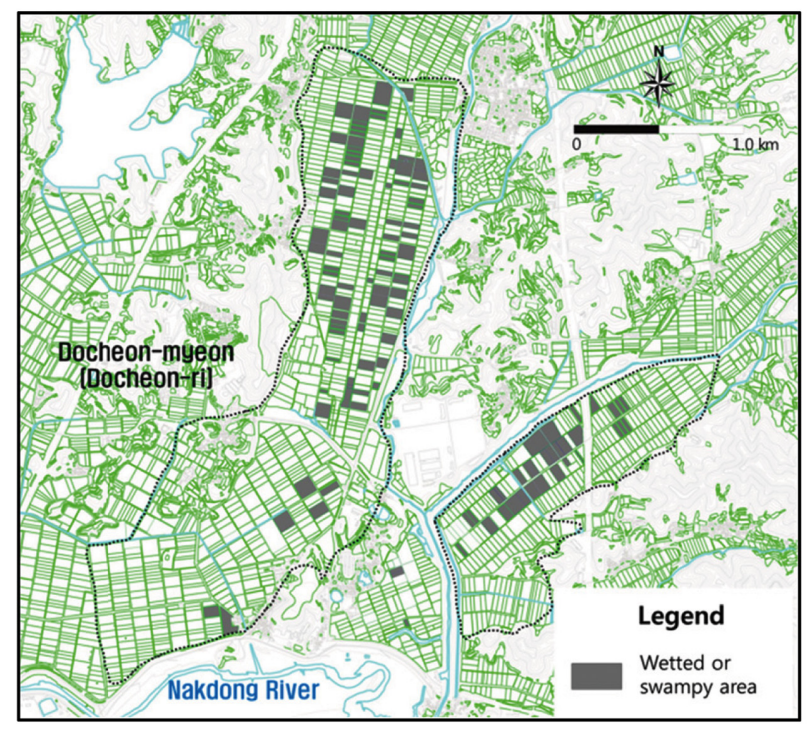

(f) Docheon-ri area
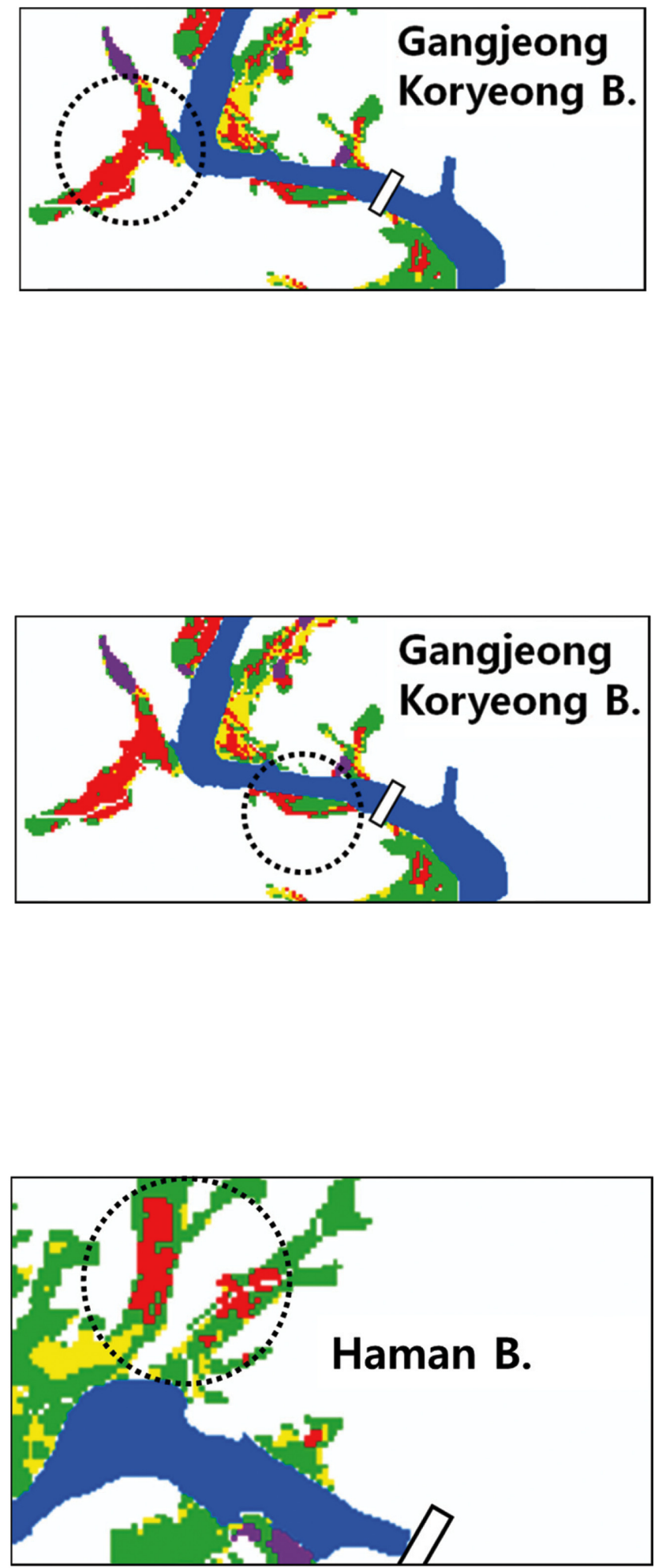
numerical model results. Though there can be some errors in the map due to uncertainties of model input variables such as soil and topography, the final map can help us to prevent groundwater inundation in the riversides. Our study highlights the need to carefully observe and manage highly susceptible areas, especially when high river water levels are unavoidably maintained during the rainy season.

\section{Acknowledgements}

This research was supported by the Daejeon University Research Grants (2016) scheme.

\section{References}

Adams, B., Bloomfield, J.P., Gallagher, A.J., Jackson, C.R., Rutter, H.K., and Williams, A.T., 2010, An early warning system for groundwater flooding in the Chalk. Quaternary Journal of Engineering Geology and Hydrogeology, v. 43, pp. 185-193.

Chen, X., and Hu, Q., 2004, Groundwater influences on soil moisture and surface evaporation. Journal of Hydrology, v. 297, pp. 285-300.

Cobby, D., Morris, S., Parkes, A., and Robinson, V., 2009, Groundwater flood risk management: advances towards meeting the requirements of the EU Floods Directive. Journal of Flood Risk Management, v. 2, pp. $111-119$.

Dreher, J., and Gunatilaka, A., 1996, Groundwater management in the city of Vienna: modelling, testing \& monitoring for hydro power plants-II. International Journal of Hydropower and Dams, v. 2, pp. 545-554.

Dreher, J., and Gunatilaka, A., 1998, Groundwater management system in Vienna - an evaluation after three years of operation. In: Peters, J., and Jensen, K.J. (Eds.), Artificial Recharge of Groundwater. Balkema, Amsterdam, pp. 167-172.

Habets, F., Boone, A., Champeaux, J.L., Etchevers, P., Franchistéguy, L., Leblois, E., Ledoux, E., Le Moigne, P., Martin, E., Morel, S., Noilham, J., Quintana Seguí, P., Rousset-Regimbeau, F., and Viennot, P., 2008, The SAFRAN-ISBA-MODCOU hydrometeorological model applied over France. Journal of Geophysical Research, v. 113, D06113. https:// doi.org/10.1029/2007JD008548

Habets, F., Gascoin, S., Korkmaz, S., Thiéry, D., Zribi, M., Amraoui, N., Carli, M., Ducharne, A., Leblois, E., Ledoux, E., Martin, E., Noilhan, J., Ottle, C., and Viennot, P., 2010, Multi-model comparison of a major flood in the groundwater-fed basin of the Somme River (France). Hydrology and Earth Systems Science, v. 14, pp. 99-117.

Healy, R.W., and Cook, P.G., 2002, Using groundwater levels to estimate recharge. Hydrogeology Journal, v. 10, pp. 91-109.

Hughes, A.G., Vounaki, T., Peach, D.W., Ireson, A.M., Jackson, C.R., Butler, A.P., Bloomfield, J.P., Finch, J., and Wheater, H.S., 2012, Flood risk from groundwater: examples from a chalk catchment in southern England. Journal of Flood Risk Management, v. 4, pp. 143-155.

Kim, G.B., Son, Y.C., Lee, S.H., Jeong, A.C., Cha, E.J., and Ko, M.J., 2012, Understanding of surface water-groundwater connectivity in an alluvial plain using statistical methods. Journal of Engineering Geology, v. 22, pp. 207-221.

Kim, G.B., Cha, E.J., Jeong, H.G., and Shin, K.H., 2013, Comparison of time series of alluvial groundwater levels before and after barrage construction on the lower Nakdong River. Journal of Engineering Geology, v. 23, pp. 1-11.

Kim, G.B., 2014, Optimal distribution of groundwater monitoring wells near the river barrages of the 4MRRP using a numerical model and topographic analysis. Environmental Earth Sciences, v. 73, pp. 54975511.

Kim, G.B., Cha, E.J., and Shin, K.H., 2014, Development and applicability of flood vulnerability index using groundwater levels. Journal of the Geological Society of Korea, v. 50, pp. 257-268.

Kim, T.H., Lee, S.H., and Kim, G.B., 2015, Prediction model for groundwater flooding vulnerability using discriminant analysis at riverside region. Journal of the Geological Society of Korea, v. 51, pp. 313-325.

Kreibich, H., Thieken, A.H., Grunenberg, H., Ullrich, K., and Sommer, T., 2009 , Extent, perception and mitigation of damage due to high groundwater levels in the city of Dresden, Germany. Natural Hazards and Earth Systems Science, v. 9, pp. 1247-1258.

K-water, 2013, Research on the development of groundwater flooding vulnerability assessment tool. Daejeon, $240 \mathrm{p}$.

Lee, J.H., Hamm, S.Y., Lee, C.M., Lee, J.J., Kim, H.S., and Kim, G.B., 2012, Numerical simulation of groundwater system change in a riverside area due to the construction of an artificial structure. Journal of Engineering Geology, v. 22, pp. 263-274.

MacDonald, A.M., Hughes, A.G., Vounaki, T., Graham, M.T., Lilly, A., Mansour, M., Stephens, C.A., 2008, Groundwater and the Forres (River Findhorn \& Pilmuir) flood alleviation schemes. British Geological Survey Commissioned Report CR/08/023, Nottingham, England, 82 p.

MLTM (Ministry of Land, Transportation, and Maritime Affairs), 2010, Plan for the construction and management of groundwater monitoring wells at the four major rivers restoration project regions. Seoul, Korea, $278 \mathrm{p}$.

MLTM (Ministry of Land, Transport and Maritime Affairs), 2012, Master plan for groundwater management in Korea (2012-2021). Seoul, Korea, 154 p.

MLTM (Ministry of Land, Transportation, and Maritime Affairs), 2013, Research on the establishment of the management system for groundwater along the four main rivers. Seoul, Korea, $366 \mathrm{p}$.

Mucha, I., 1999, Plenipotentiary of the Slovak Republic for construction and operation of Gabčikovo-Nagymaros hydropower scheme; Gabčikovo part of the hydroelectric power project environmental impact review. Ground Water Consulting Ltd., Bratislava, Slovakia, 399 p.

Naughton, O., Johnson, P.M., and Gill, L.W., 2012, Groundwater flooding in Irish karst: The hydrological characterization of ephemeral lakes (Turloughs). Journal of Hydrology, v. 470-471, pp. 82-97.

Nielsen, R.D., and Hjelmfelt, A.T., 1998, Hydrologic soil group assessment. Water Resources Engineering 98: Proceedings of the International Water Resources Engineering Conference, 1998, American Society of Civil Engineers, Abstract, pp. 1297-1302.

Shlemon, R.J., 1995, Groundwater rise and hydrocollapse: technical and political implications of "Special Geologic Report Zones" in Riverside County, California, USA. Proceedings of the Fifth Symposium on Land Subsidence, IAHS Publication No. 234, pp. 481-486.

Sommer, T., Karpf, C., Ettrich, N., Haase, D., Weichel, T., Peetz, J.V., Steckel, B., Eulitz, K., and Ullrich, K., 2009, Coupled modeling of subsurface water flux for an integrated flood risk management. Natural Hazards and Earth System Science, v. 9, pp. 1277-1290.

Sommer, T., and Ullrich, K., 2005, Influence of flood event 2002 on groundwater. Environmental Office, City of Dresden, $68 \mathrm{p}$.

UKELA (UK Environmental Law Association), 2017, Law \& your Environment: The plain guide to environmental law. http://www.environmentlaw.org.uk/rte.asp?id=100 [accessed $23^{\text {rd }}$ April 2017].

USDA (U.S. Department of Agriculture, Natural Resources Conservation Service), 2005, National soil survey handbook, title 430-VI. Washington, DC. Available online at http://soils.usda.gov/technical/handbook/ 


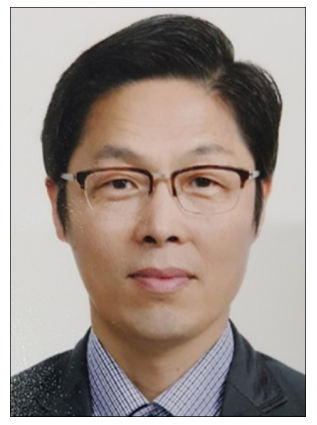

Gyoo-Bum Kim is a Professor at the Department of Construction Safety and Disaster Prevention in Daejeon University, Republic of Korea. Vice President of the Geological Society of Korea. Published more than 90 papers and 17 patents on groundwater technology. Vast experince in implementation of research and investigation projects concerned groundwater hydrology, geochemistry, geothermal energy, database, monitoring, and water policy over the last 28 years.

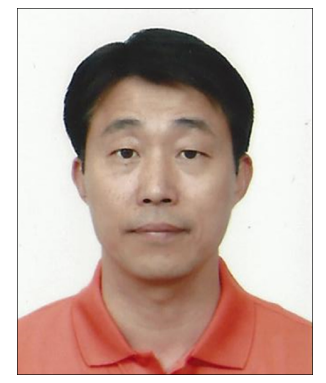

Deog-Geun Kim is a Senior Manager at K-water Convergence Institute in Korea Water Resources Corporation (K-water), Republic of Korea. Over 20 -year experience on groundwater hydrology and geotechnical engineering. Praticipated in over 70 research and investigation projects concerned groundwater hydrology, management policy and geotechnical engineering. 